\title{
Effects of Harvest Time on the Aroma of White Wines Made from Cold-Hardy Brianna and Frontenac Gris Grapes Using Headspace Solid-Phase Microextraction and Gas Chromatography-Mass Spectrometry-Olfactometry
}

\author{
Somchai Rice ${ }^{1,2,3} \mathbb{C}^{-}$, Madina Tursumbayeva ${ }^{3}{ }^{-}$, Matthew Clark ${ }^{4}$, David Greenlee ${ }^{5}$, \\ Murlidhar Dharmadhikari ${ }^{1}$, Anne Fennell ${ }^{6}$ (D) and Jacek A. Koziel ${ }^{3, *(D)}$ \\ 1 Midwest Grape and Wine Industry Institute, Iowa State University, Ames, IA 50011, USA; \\ somchai@iastate.edu (S.R.); murli@iastate.edu (M.D.) \\ 2 Interdepartmental Toxicology Graduate Program, Iowa State University, Ames, IA 50011, USA \\ 3 Department of Agricultural and Biosystems Engineering, Iowa State University, Ames, IA 50011, USA; \\ madina@iastate.edu \\ 4 Department for Horticultural Science, University of Minnesota, St. Paul, MN 55108, USA; clark776@umn.edu \\ 5 Tucker's Walk Vineyard and Winery, Garretson, SD 57030, USA; dave@tuckerswalk.com \\ 6 Department of Agronomy, Horticulture and Plant Science, BioSNTR, South Dakota State University, \\ Brookings, SD 57006, USA; anne.fennell@sdstate.edu \\ * Correspondence: koziel@iastate.edu; Tel.: +1-515-294-4206
}

Received: 20 December 2018; Accepted: 10 January 2019; Published: 16 January 2019

\begin{abstract}
The Midwest wine industry has shown a marked increase in growers, hectares planted, wineries, and wine production. This growth coincides with the release of cold-hardy cultivars such as Brianna and Frontenac gris, in 2001 and 2003, respectively. These white grape varieties account for one-third of the total area grown in the state of Iowa. It is generally accepted that the wine aroma profile plays a crucial role in developing a local, sustainable brand. However, the identity of Brianna/Frontenac Gris-based wine aromas and their link to the grape berry chemistry at harvest is unknown. This study aims to preliminarily characterize key odor-active compounds that can influence the aroma profile in wines made from Brianna and Frontenac gris grapes harvested at different stages of ripening. Brianna and Frontenac gris grapes were harvested approximately 7 days apart, starting at $15.4^{\circ} \mathrm{Brix}(3.09 \mathrm{pH})$ and $19.5^{\circ}$ Brix $(3.00 \mathrm{pH})$, respectively. Small batch fermentations were made for each time point with all juices adjusted to the same ${ }^{\circ}$ Brix prior to fermentation. Odor-active compounds were extracted from wine headspace using solid-phase microextraction (SPME) and analyzed by gas chromatography-mass spectrometry (GC-MS) and simultaneous olfactometry $(\mathrm{O})$. Over 30 odor-active compounds were detected. Aromas in Brianna wines developed from "cotton candy" and "floral", to "banana" and "butterscotch", then finally to "honey", "caramel" and an unknown neutral aroma. Frontenac gris wines changed from an unknown neutral aroma to "fruity" and "rose". Results from the lay audiences' flavor and aroma descriptors also indicate a shift with harvest date and associated ${ }^{\circ}$ Brix. To date, this is the first report of wine aromas from Brianna and Frontenac gris by GC-MS-O. Findings from this research support the hypothesis that aroma profiles of Brianna and Frontenac gris wines can be influenced by harvesting the grapes at different stages of ripening.
\end{abstract}

Keywords: Frontenac gris; Brianna; wine aroma; SPME-GC-MS; olfactometry; cold-hardy grapes 


\section{Introduction}

The business of grapes and wine generated over $\$ 7.5$ billion U.S. dollars (USD) in the upper Midwestern states of Iowa, Illinois, Michigan, Minnesota, North Dakota, South Dakota, and Wisconsin in 2017 [1]. This included the direct economic impact from vineyard and winery activities as well as tourism, resulting in over 110,000 jobs and over $\$ 3$ billion in wages (Table 1).

Table 1. Economic impact of the U.S. Midwest (cold climate) wine industry [1].

\begin{tabular}{cccccccc}
\hline State & $\begin{array}{c}\text { Economic } \\
\text { Impact }^{\mathbf{1}}\end{array}$ & Jobs & Wages $\mathbf{1}^{\mathbf{1}}$ & $\begin{array}{c}\text { Vineyard } \\
\text { Activity }\end{array}$ & $\begin{array}{c}\text { Winery } \\
\text { Activity }\end{array}$ & Tourism ${ }^{\mathbf{1}}$ & Other $^{\mathbf{1}, 2}$ \\
\hline North Dakota & $\$ 135$ & 2340 & $\$ 57.3$ & $\$ 0.00680$ & $\$ 7.09$ & $\$ 0.245$ & $\$ 127$ \\
South Dakota & $\$ 180$ & 2690 & $\$ 62.4$ & $\$ 0.0719$ & $\$ 25.7$ & $\$ 1.69$ & $\$ 153$ \\
Iowa & $\$ 573$ & 8760 & $\$ 197$ & $\$ 1.10$ & $\$ 110$ & $\$ 29.0$ & $\$ 433$ \\
Minnesota & $\$ 979$ & 15,400 & $\$ 408$ & $\$ 1.22$ & $\$ 83.5$ & $\$ 21.3$ & $\$ 873$ \\
Wisconsin & $\$ 1320$ & 20,700 & $\$ 519$ & $\$ 1.12$ & $\$ 146$ & $\$ 39.7$ & $\$ 1130$ \\
Michigan & $\$ 1890$ & 25,800 & $\$ 710$ & $\$ 7.77$ & $\$ 325$ & $\$ 149$ & $\$ 1410$ \\
Illinois & $\$ 2480$ & 34,800 & $\$ 1060$ & $\$ 1.82$ & $\$ 247$ & $\$ 222$ & $\$ 2010$ \\
\hline Totals & $\$ 7550$ & 11,0000 & $\$ 3010$ & $\$ 13.1$ & $\$ 944$ & $\$ 463$ & $\$ 6130$ \\
\hline
\end{tabular}

${ }^{1}$ Millions of U.S. Dollars (USD); ${ }^{2}$ includes wholesale, retail, associations, research, and education.

In Iowa, the number of grape growers, vineyards of grapes, wineries, and wine production has increased in the last two decades (Figures 1 and 2) [2]. In a report by Tuck and Gartner in 2014, 100 hectares of grapes planted in Iowa were of the cold-hardy white varieties [3]. These numbers were extrapolated from self-reported surveys to determine the baseline of activity involving cold-hardy grape varieties. Of this estimated 100 hectares, $27 \%$ of the plantings were Frontenac gris and Brianna varieties.

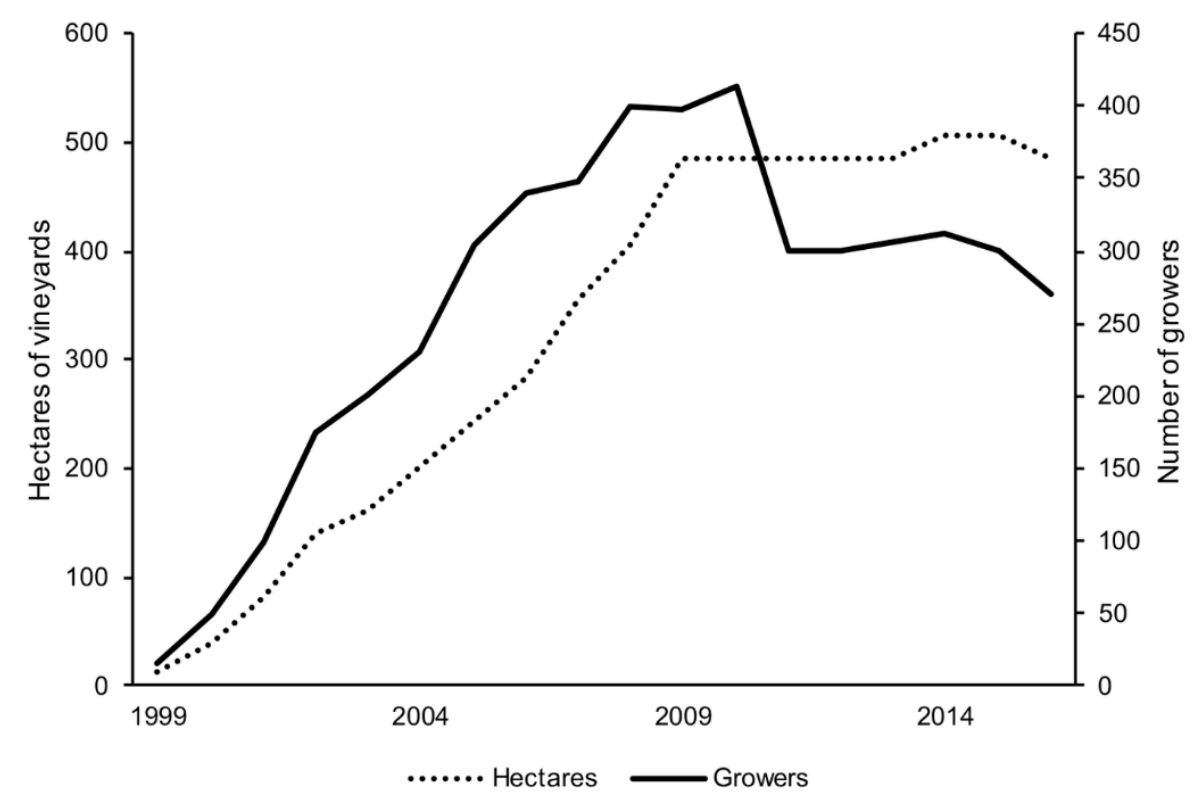

Figure 1. The increase in hectares of wine grapes and the number of growers in Iowa [2]. 


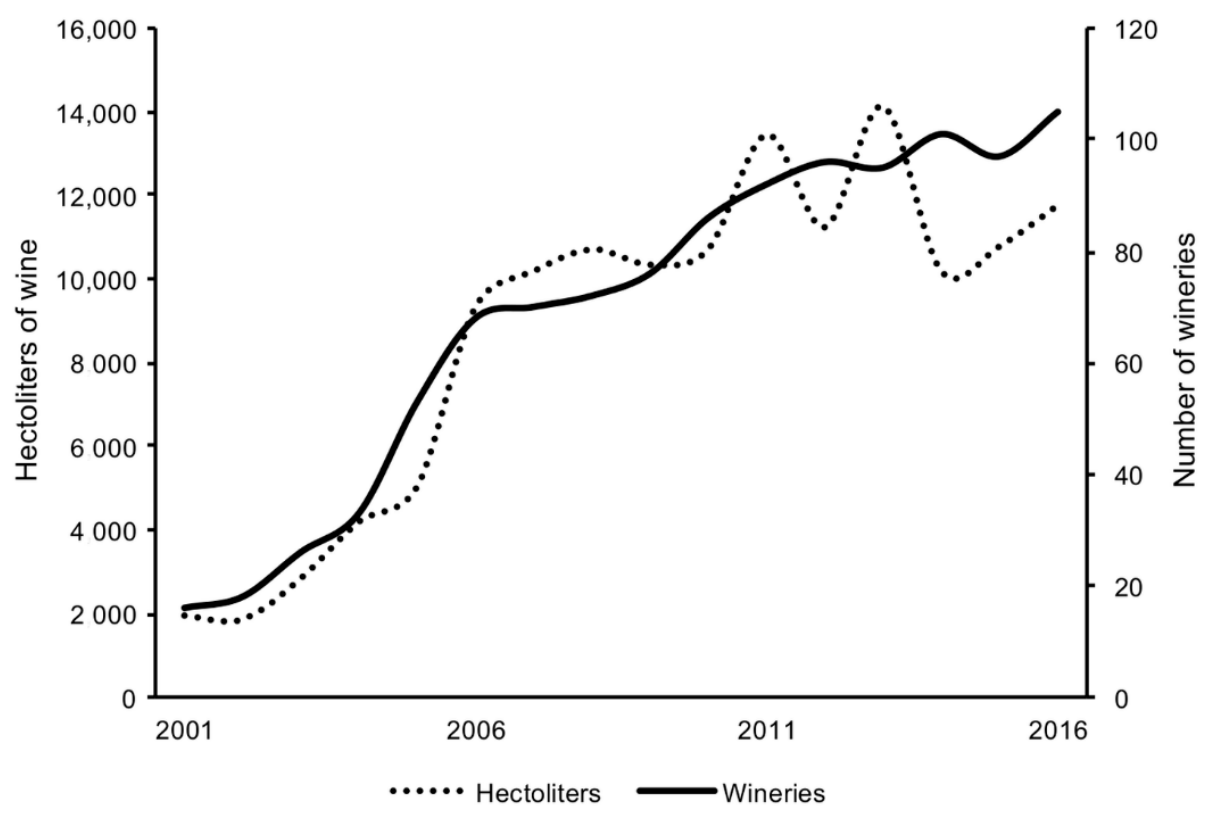

Figure 2. The increase in wine production (hectoliters) and a number of wineries in Iowa [2].

There is continuous interest in understanding the chemical origin of grape aromas. Our working hypothesis is that this information could help growers and winemakers to determine a more targeted harvest date, based on the desired aromas. It also would allow an assessment of how various winemaking practices influence aroma, an important factor of wine quality. This information could streamline the production of new grape varieties by permitting the selection of varieties showing certain aromatic attributes. Despite these advantages, determining the chemical origin of varietal aromatic character is complicated. First, odor-active compounds in grapes often occur in nonvolatile forms. These compounds are released only upon crushing [4], through yeast metabolism [5], or during aging [6]. A varietal character can originate from a combination of compounds and not from varietal specific compounds. Extraction procedures may influence the stability of odor-active compounds. Identification and quantification of odor-active compounds are needed to understand the aroma potential of new cold-hardy grape varieties.

The added benefit of simultaneous olfactometry $(\mathrm{O})$ and chemical analysis (e.g., by gas chromatography-mass spectrometry (GC-MS)) allows for characterization of trace amounts of compounds with detection limits below that of the mass detector (i.e., 2-isobutyl-3-methoxypyrazine, a "green bell pepper" aroma with detection threshold less than $0 \mathrm{ppb}$ ) $[7,8]$. Brianna is known, at least anecdotally within the industry, to develop an unwanted "foxy" aroma if harvested after $14-16^{\circ}$ Brix. However, there is a lack of scientific data to support this observation.

Grape maturity levels expressed by sugar content (measured as ${ }^{\circ}$ Brix) and titratable acidity (TA) in grape berries has a great impact on wine quality and aroma as well. During the period of grape ripening, sugar content increases in berries while the TA level decreases. The relationship between those two factors affects the release of wine odor-active compounds. As sugar increases and acidity decreases, the aroma of wine changes from "herbal" to "fruity" [9]. However, higher sugar content in berries resulting in higher ethanol production can decrease the volatility of odor-active compounds in wine, and fruity aromas change to alcohol-associated aromas [10]. Grapes are typically harvested when $\mathrm{pH}$ levels are between 3.2 to 3.4 for Brianna [11] and around 3.0 for Frontenac gris [12]. Brianna fruit has "grapefruit, tropical" and slight "floral" characteristics [11]. Frontenac gris fruit has aromas of "peach, apricot" and "tropical fruits" [13]. These cold-hardy cultivars were introduced to the public in 2001 (Brianna) [11] and 2003 (Frontenac gris) [12]. The cultivars are advantageous in cold climates, where $V$. vinifera will not survive the extreme low temperatures. Brianna was shown to be a top yielding cultivar among select cold-hardy cultivars with the lowest average titratable acidity [14]. 
There is a need to characterize aromas from these new cold-hardy cultivars in order to understand and improve the potential of the final product. The objective of this study was to preliminarily associate odor-active compounds in Brianna and Frontenac gris white wines with different stages of grape berry ripening (i.e., with increasing sugar content and $\mathrm{pH}$ ). This was completed by analyzing odor-active compounds in the headspace of wine using solid-phase microextraction (SPME) and simultaneous chemical and sensory analysis using gas chromatography-mass spectrometry-olfactometry (GC-MS-O) [15,16].

In our previous research, we developed an automated headspace SPME-GC-MS-O method for aroma profiles of seven cold-hardy wines [15]. The effects of the SPME fiber type (7 coatings), the headspace SPME extraction time (10 distinct times from $10 \mathrm{~s}$ to $1 \mathrm{~h}$ ), the extraction temperature ( 6 set points from 35 to $80^{\circ} \mathrm{C}$ ), the incubation time ( 5 set points for headspace equilibration from 0 to $20 \mathrm{~min}$ ), the sample volume (4 set points from 1 to $4 \mathrm{~mL}$ in a $10 \mathrm{~mL}$ vial), the desorption time (6 set points from 30 to $300 \mathrm{~s}$ ), and the salt addition (5 set points) were tested. We used the optimized SPME conditions from previous research [15] in this current work. A multivariate analysis was used to illustrate the effects of harvest time on wine odor-active compounds. There is a need to characterize aromas from these new cold-hardy cultivars in order to understand and improve the potential of the final product. This is the first report of odor-active compounds in wines made from Frontenac gris and Brianna grapes at different levels of maturity. Information from this study can guide growers and winemakers in optimizing winemaking techniques and harvest decisions. This (GC-O) technique has been used in wine aroma analysis in Chardonnay [17], Muscat [18], Cabernet Gernischt, Cabernet Sauvignon, Cabernet Franc, Merlot [19], and native American grapes (Vitis) [20].

\section{Materials and Methods}

\subsection{Grape Samples Collection and Winemaking}

The working hypothesis is that wine aromas are affected by Brianna and Frontenac gris berry maturation (i.e., change in $\mathrm{pH}$ and sugar content as ${ }^{\circ}$ Brix) at the time of harvest. Brianna and Frontenac gris grapes were grown in a Tucker's Walk vineyard in Garretson, South Dakota. Brianna and Frontenac gris grapes' characteristics at harvest are given in Table 2. Tucker's Walk produced the wines using the protocols developed for the Northern Grapes Project [21] during the 2015 growing season and are described as follows. Briefly, grapes were harvested approximately one week apart. Four small batches of Brianna and three small batches of Frontenac gris wines were made on-site, $(n=2)$, using the same winemaking process. Grapes (110 to $120 \mathrm{~kg}$ ) were processed in a crusher/destemmer and pressed, and juice sugar content was adjusted to $24^{\circ}$ Brix for Frontenac gris and $20^{\circ}$ Brix for Brianna. Frontenac gris, a bud sport from Frontenac and a high acid grape, is typically harvested for commercial wine at 22-24 ${ }^{\circ}$ Brix. Brianna, a low acid grape, is typically harvested between 16 and 20 Brix. Brianna and Frontenac gris juices were brought to 20 and $24^{\circ}$ Brix, respectively, at each harvest time point and fermented to dryness. This provided the same alcohol content in the respective cultivars across harvest dates. Inoculated juice was allowed to start fermenting at ambient temperature for $24 \mathrm{~h}$, then immediately moved into $13{ }^{\circ} \mathrm{C}$ and fermented to dryness. The wines ( 14 total) were analyzed by chemical and sensory analysis in triplicate. 
Table 2. Brianna and Frontenac gris grapes' characteristics at harvest.

\begin{tabular}{cccc}
\hline Cultivar & Harvest Date & Berry $^{\circ}$ Brix & Berry $\mathbf{~ H}$ \\
\hline Frontenac gris & 24 September 2015 & 19.5 & 3.00 \\
Frontenac gris & 1 October 2015 & 23.1 & 3.06 \\
Frontenac gris & 9 October 2015 & 23.6 & 3.18 \\
Brianna & 4 September 2015 & 15.4 & 3.09 \\
Brianna & 11 September 2015 & 17.6 & 3.19 \\
Brianna & 18 September 2015 & 18.6 & 3.29 \\
Brianna & 25 September 2015 & 19.6 & 3.45 \\
\hline
\end{tabular}

\subsection{Informal Sensory Analysis of Brianna Wine by Wine Industry Professionals}

Wines from each fermentation were analyzed in blind tastings by lay audiences at two viticulture and enology conferences (Minnesota Cold Climate Conference and Nebraska Vindemia). These panelists included grape growers, winemakers, vineyard/winery owners, and research scientists. Data was gathered from 32 and 23 individuals, respectively, and pooled for analysis. The panelists were asked to provide flavor descriptors and any wine quality notes. The descriptive terms were generated by the audience members and extracted from the data sheets. The terms were reduced from 78 to 61 terms by combining similar terms. For example, "citrus" includes lemon, lemongrass, grapefruit, and lime. The top 24 terms were selected as those having been mentioned by at least 4 panelists. A spider plot was created using the term's incidence as the response variable.

\subsection{Preparation of Wine Samples}

A $10 \mathrm{~mL}$ glass amber vial with a magnetic screw top and polytetrafluoroethylene (PTFE)-lined septum was used. Undiluted wine samples and serial dilutions of wine samples in model wine $(4 \mathrm{~mL}$ total volume) were prepared using dilution factors of 2, 4, 8, 16, and 32 [22]. The model wine was $5 \mathrm{mg} / \mathrm{mL}$ of potassium bitartrate in $12 \%$ ethanol in water. Two $\mathrm{g}$ of sodium chloride was added to each $10 \mathrm{~mL}$ vial to enhance headspace SPME extraction.

\subsection{Automated SPME Extraction}

A 50/30 $\mu \mathrm{m}$ divinylbenzene (DVB)/Carboxen/polydimethylsiloxane (PDMS) SPME fiber (Sigma-Aldrich, St. Louis, MO, USA) was used to extract and pre-concentrate odor-active compounds from the headspace of wine samples. A Leap Technologies CombiPal (Trajan Scientific, Pflugerville, TX, USA) was used for automated headspace sampling with the following parameters: $500 \mathrm{rpm}$ agitation speed during incubation and extraction, $10 \mathrm{~min}$ incubation/extraction time at $50{ }^{\circ} \mathrm{C}$, and $260{ }^{\circ} \mathrm{C}$ desorption for 2 min directly into the GC inlet. To prevent carryover between samples, the SPME fiber was also cleaned in a needle heater $\left(260^{\circ} \mathrm{C}\right.$ for $\left.2 \mathrm{~min}\right)$ under a flow of clean helium prior to each analysis.

\subsection{Chemical and Sensory Analysis}

An Agilent (7890B and 5977A) GC-MS was used for analysis, fitted with two columns in series. The first column was non-polar (BPX-2, $83 \mathrm{~m} \times 530 \mu \mathrm{m} \times 0.5 \mu \mathrm{m}$, SGE-Trajan Scientific, Pflugerville, TX, USA) and pressure balanced at the midpoint with a second polar column (DB-WAXETR, $30 \mathrm{~m} \times 530 \mu \mathrm{m} \times 0.25 \mu \mathrm{m}$, Agilent Technologies, Santa Clara, CA, USA). Effluent from the second column was split 1:3 by restrictor columns to the single quadrupole mass spectrometer and olfactometry sniff port, respectively (1 part to MS and 2 parts to O-port). The GC temperature profile was initially $40^{\circ} \mathrm{C}$, held for $3 \mathrm{~min}, 7^{\circ} \mathrm{C} / \mathrm{min}$ ramp to $220^{\circ} \mathrm{C}$, held for $11.29 \mathrm{~min}$. Data acquisition was collected in full scan mode, the mass range was $\mathrm{m} / \mathrm{z} 33$ to 450 , and the electron ionization energy was $70 \mathrm{eV}$. The instrument was tuned daily prior to analysis. MassHunter (v. B.07.00.1413, Agilent, Santa Clara, CA, USA) was used for mass spectral data acquisition and analysis. AromaTrax (v. 10.1, MOCON, Round Rock, TX, USA) was used for sensory data acquisition (i.e., the aromagram). Multitrax Multidimensional Control 
Software (v. 10.1, MOCON, Round Rock, TX, USA) was used for pressure balance programming. A single trained human panelist was used to assign aroma descriptors and intensity to each compound. This initial research on the popular two cold-hardy varieties was a "screening"-type work aiming to find odor-active compounds. At this (screening) stage, using one panelist is sufficient to achieve the stated aims, i.e., to preliminarily characterize odor-active compounds. This information should be used for follow-up studies as a starting point for proper experimental design. Since ethanol was expected to be present in each sample, the intensity of ethanol was assigned as 50 on a 1 to 100 intensity scale. This process has been described in detail elsewhere [22,23].

\subsection{Data Analysis}

Odor-active compounds collected from wine headspace was tentatively identified by matching mass spectra to the NIST11 library, Wiley $6 \mathrm{~N}$ library. All compounds with $80 \%$ spectral match or higher and above the 1000 peak area count threshold were considered for the analyses. Aroma descriptors from the panelist were compared to known aroma descriptors for additional verification. The matching of retention time indices was not appropriate in this case due to the GC columns of different polarity in-series configurations. The identification of compounds by the analysis of the pure standard was not performed, but the specific ions of a compound are provided in Table A1, when present in the chromatogram above the threshold.

Aroma extract dilution analysis (AEDA) was used to identify the most important compounds. From the aromagram, the odor dilution (OD) of each aroma event was multiplied by the measured intensity value resulting in the weighted intensity. This data was plotted with intensity (\% full-scale) vs. time. Compounds with a higher OD were considered to be major contributors to the aroma profile of the wine.

Aroma descriptor intensity and OD were analyzed by principal components analysis (PCA) and cluster summary analysis using JMP Pro 12.0.1 (SAS, Cary, NC, USA). PCA is useful in summarizing all the odor-active compounds, detected by the human nose, in the wines among all conceivable linear combinations. A cluster summary analysis was also performed to determine the most representative aroma compound (i.e., the cluster variable with the largest squared correlation with its cluster component).

\section{Results}

Aroma events were simultaneously recorded using the sniff port by a trained human panelist during chromatographic analysis. A summary of the aroma events and the tentative identification by mass spectra is given in Table A1 in Appendix A. There were 57 unique aroma events detected by olfactometry and 32 odor-active compounds tentatively identified by mass spectrometry in Frontenac gris and Brianna wines. There were 35 and 34 aroma events recorded for Frontenac gris and Brianna wines, respectively. Aroma descriptors that were common between Frontenac gris and Brianna wines included "alcoholic, banana, body odor, butterscotch, cut grass, floral, fruity, garlic, honey, caramel, overripe fruit, rose, rotten eggs, solvent, strawberry", and "tomato". Aroma descriptors unique to Frontenac gris wines included "woody, carrots, cereal, mushroom, sweaty", and "vinegar". Aroma descriptors unique to Brianna wines included "barnyard, cotton candy, and mint." The intensity of aromas (detailed in Materials and Methods section) in Frontenac gris and Brianna wines, according to harvesting parameters, is summarized in Table 3. 
Table 3. Summary of the ranked weighted intensity of aromas (recorded by olfactometry) in wine made from Frontenac gris and Brianna grapes harvested at different stages of ripening. All juice was brought to $24^{\circ}$ Brix for Frontenac gris and $20^{\circ}$ Brix for Brianna prior to fermentation to ensure similar alcohol content in the wines from the different time points.

\begin{tabular}{|c|c|c|c|}
\hline Cultivar & Berry ${ }^{\circ}$ Brix & Berry pH & Aroma Descriptors (Weighted Intensity ${ }^{1}$ ) \\
\hline Frontenac gris & 19.5 & 3.00 & $\begin{array}{l}\text { unknown pleasant (19), floral/fruity (11), floral (5), overripe } \\
\text { (3), butterscotch (2), tomato (1), unknown pleasant } 1(0) \text {, } \\
\text { unknown neutral } 2(0)\end{array}$ \\
\hline Frontenac gris & 23.1 & 3.06 & $\begin{array}{l}\text { honey/caramel/butterscotch (431), fruity (419), cut } \\
\text { grass/fruity (417), alcoholic (391), banana (382), body odor } \\
\text { (359), fruity } 1 \text { (345), solvent (337), unknown pleasant (324), } \\
\text { rose } 2 \text { (321), garlic (207), carrots/woody (178), cereal (152), } \\
\text { honey (122), vinegar (57), woody } 1 \text { (55) }\end{array}$ \\
\hline Frontenac gris & 23.6 & 3.18 & $\begin{array}{l}\text { strawberry (524), strawberry/honey (395), sweaty (384), } \\
\text { fruity } 2 \text { (244), match/sulfury (183), rose } 1 \text { (132), fecal (117), } \\
\text { woody } 2 \text { (102), rotten eggs/sulfury (78), mushroom (63), } \\
\text { unknown neutral } 1 \text { (5) }\end{array}$ \\
\hline Brianna & 15.4 & 3.09 & $\begin{array}{l}\text { rose (158), body odor (123), barnyard (122), butterscotch } 2 \\
\text { (115), unknown pleasant (111), unknown neutral } 2 \text { (98), } \\
\text { matchstick (92), mint (67), cotton candy (13) }\end{array}$ \\
\hline Brianna & 17.6 & 3.19 & alcoholic (420), overripe fruit 2 (373), rotten eggs (106) \\
\hline Brianna & 18.6 & 3.29 & $\begin{array}{l}\text { strawberry } 2 \text { (579), fruity } 3 \text { (506), cut grass (500), floral/fruity } \\
\text { (472), honey/caramel (468), banana (467), overripe fruit } 1 \\
\text { (455), solvent (425), strawberry } 1 \text { (382), unknown neutral } 3 \\
\text { (363), fruity } 2 \text { (316), garlic (239), unknown pleasant (193), } \\
\text { fruity } 1 \text { (21), floral (5) }\end{array}$ \\
\hline Brianna & 19.6 & 3.45 & $\begin{array}{l}\text { tomato } 2 \text { (196), unknown neutral } 4 \text { (194), unknown neutral } 5 \\
\text { (180), tomato } 1 \text { (179), unknown neutral } 1 \text { (59), fruity } 4 \text { (45), } \\
\text { butterscotch } 1 \text { (3) }\end{array}$ \\
\hline
\end{tabular}

${ }^{1}$ Defined in the Materials and Methods (Section 2.6).

Seventeen aromas did not yield suitable $(>80 \%)$ corresponding mass spectral matches and are labeled as "unknown". This could indicate that the compound responsible for this aroma is not concentrated enough for the mass detector to respond and that the odor detection threshold for this compound was very low. The evidence that the human nose can be more sensitive than the chemical detector is consistent with the notion that simultaneous chemical and sensory analyses are useful for analyses of complex wine headspace. Wine headspace aroma is one of the first attributes experienced by consumers and wine enthusiasts.

\subsection{Frontenac Gris White Wine Aroma Analysis by SPME-GC-MS-O}

White wines from Frontenac gris grapes had 35 recorded aroma events across all samples. Aromas of "honey, caramel, butterscotch" and "strawberry, honey" had no variation in odor dilution (OD, defined in Methods) and were not used in the multivariate analysis. The aromas with the highest intensity in the Frontenac gris wines were "banana", "fruity 2", "honey", and "unknown neutral 1 ". Cluster summary analysis of OD showed that "rotten eggs, sulfury" and "unknown neutral 1" were the most representative aromas in these Frontenac gris wine. A "rotten eggs" smell in wine is considered a wine fault due to the winemaking process and therefore not considered a characteristic aroma of the grape. A chromatographic peak was not present at the corresponding retention time for "unknown neutral 1". As $\mathrm{pH}$ and sugar accumulation in the berry increased, key odor-active compounds in these Frontenac gris wines developed from "unknown neutral 2" and "fruity 1" to "rose 1" (Figure 3). These correspond to mass spectral matches of "unknown neutral 2" to decanoic acid (CAS 334-48-5) and "fruity 1" to ethyl methylbutyrate (CAS 7452-79-1). A suitable mass spectral match 
was not found for the identification of "rose 1." An open source aroma database [7] lists the percepts of "rancid, fat" for decanoic acid and "apple, characteristic of Golden delicious" for ethyl methylbutyrate. In the Flavornet database, 16 different compounds are listed with the aroma descriptor "rose".

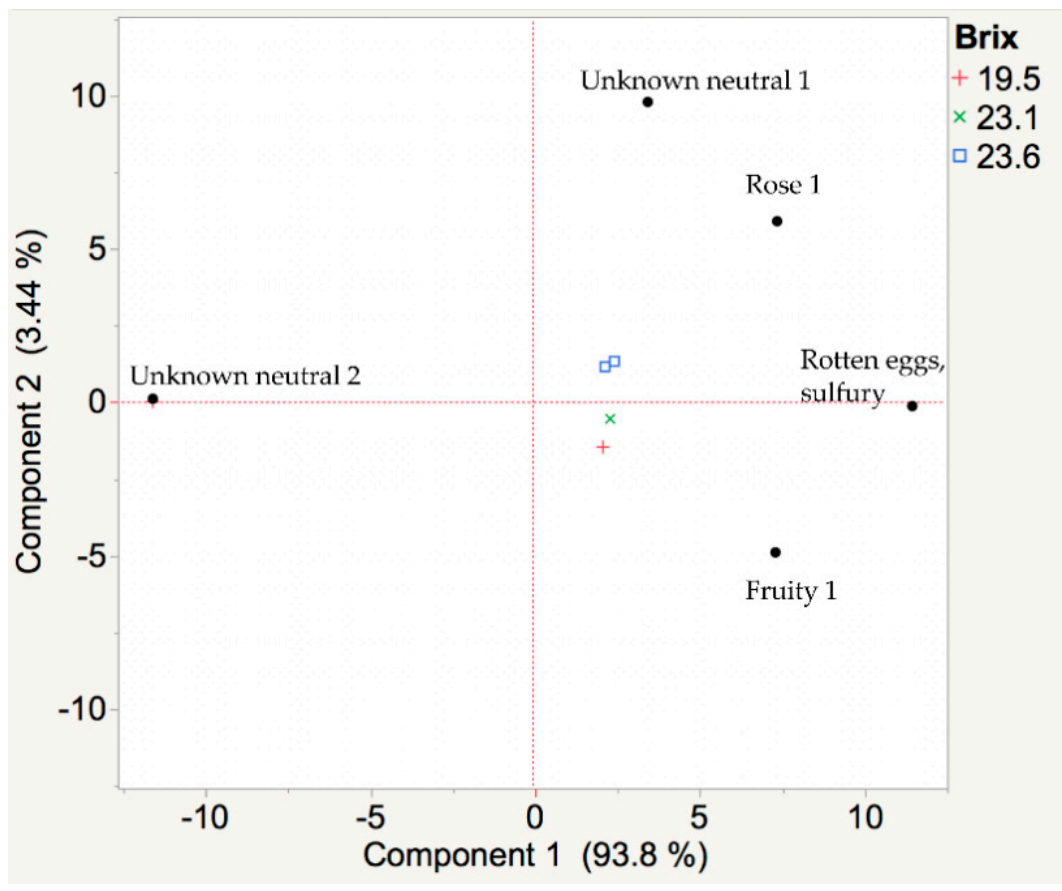

Figure 3. A principal components analysis (PCA) biplot of volatiles from the aroma extract dilution analysis of Frontenac gris wines made from berries harvested at three different ripening stages. Wines were made from Frontenac gris cold-hardy grapes harvested at 19.5, 23.1, and $23.6^{\circ}$ Brix. The juice was adjusted to $24^{\circ}$ Brix prior to fermentation. Wine headspace samples were collected by solid-phase microextraction (SPME) and analyzed with gas chromatography-mass spectrometry-olfactometry (GC-MS-O). Aroma descriptors were recorded by a trained human panelist. A shift of the aroma profile from "fruity 1"to "rotten eggs, sulfury" to "rose 1" was observed. Over $98 \%$ of the variation in harvest time is correlated with key odor-active compounds.

\subsection{Brianna White Wine Aroma Analysis by SPME-GC-MS-O}

White wine from Brianna grapes had 34 recorded aroma events across all samples. The "rotten eggs" aroma had no variation in OD and was not used in the multivariate analysis similarly to Frontenac gris. The most intense aromas in these Brianna wines were "overripe fruit 2", "floral", and "unknown neutral 5". The most representative aromas, as indicated by cluster analysis, in these Brianna wines were "banana", "floral", "honey, caramel", "butterscotch 1", "tomato 1", and "overripe fruit 2". Corresponding compounds from mass spectral searches are isoamyl acetate (banana, CAS 123-92-2), ethyl isobutyrate ("honey, caramel", CAS 97-62-1), and isoamyl alcohol ("overripe fruit 2", CAS 123-51-3). A suitable mass spectral match was not found for the "floral" aroma compound. A chromatographic peak was not recorded corresponding to "butterscotch 1", although the database lists methyl vanillate [7] as a source of this aroma. Two mass spectral matches were identified for "tomato 1": diphenylmethane ("green", CAS 101-81-5) [24] and isobutyl decanoate ("fermented", CAS 30673-38-2) [24]. The "floral" aroma is associated with 48 different compounds [7]. As $\mathrm{pH}$ and sugar accumulation in these Brianna berries increased, key odor-active compounds for each harvest changed (Figure 4). When harvested at the lowest sugar content and $\mathrm{pH}$, the wines had a "cotton candy" (ethyl decanoate, CAS 110-38-3) and "floral" aroma. From 17.6 to $18.6^{\circ}$ Brix, aromas changed from "banana" to "butterscotch." At the highest sugar and $\mathrm{pH}$, the key aromas in the Brianna wines were "honey, caramel" and "unknown 
neutral 1" (isobutyl alcohol, CAS 78-83-1). This change in aromas over Brianna berry ripening is shown in Figure 4.

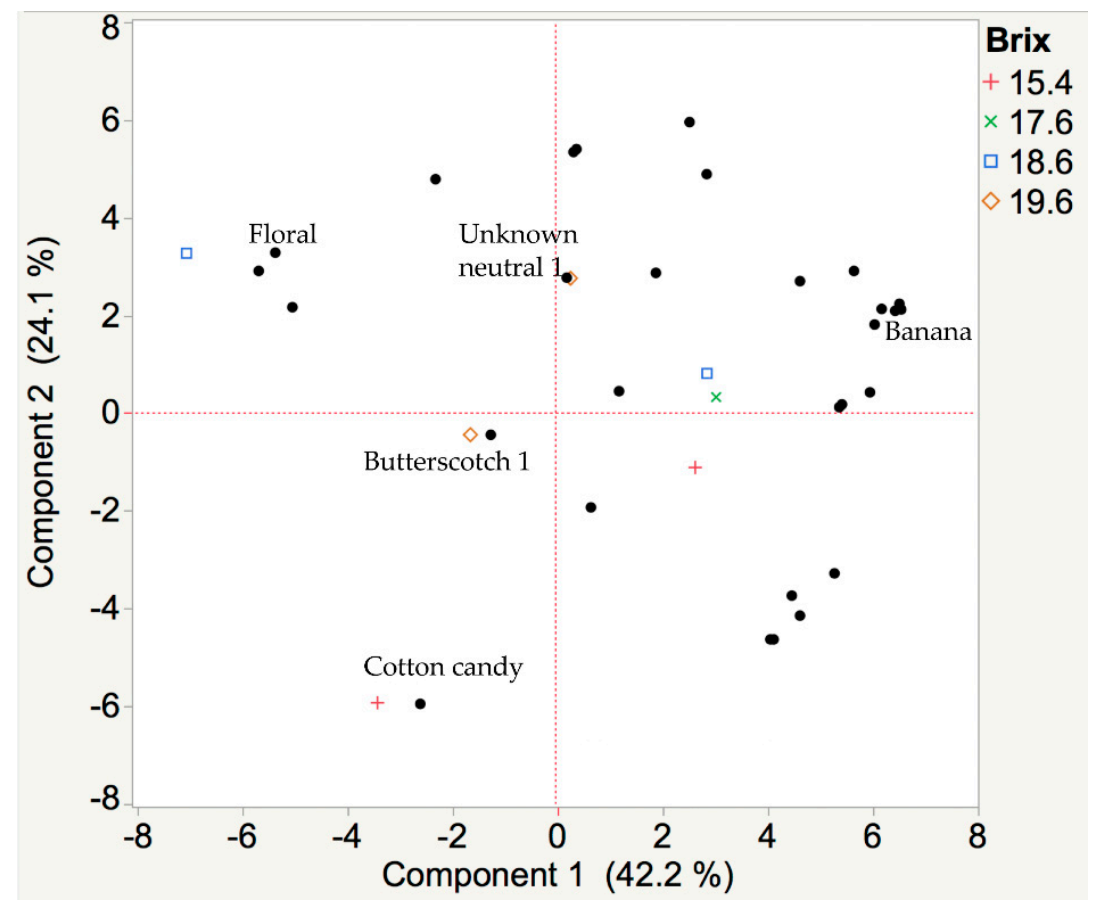

Figure 4. A PCA biplot of aromas from Brianna wines made from berries harvested at four different ripening stages. Wines were made from Brianna cold-hardy grapes harvested at 15.4, 17.6, 18.6, and 19.6 ${ }^{\circ}$ Brix. The juice was adjusted to $20^{\circ}$ Brix for all time points prior to fermentation. Wine headspace samples were collected by SPME and analyzed with GC-MS-O. Aroma descriptors were recorded by a trained human panelist. A shift of the aroma profile from "cotton candy" to "banana" to "floral" to "butterscotch" was observed. Over $68 \%$ of the variation in harvest time is correlated with key odor-active compounds.

\section{Discussion}

SPME has been used to quantify volatile by-products in industrial ethanol [25], volatile cogeners in food-grade ethanol [23], and volatile odor-active compounds in cold-hardy wines made from Marquette and Frontenac [22] and even used to characterize street drug aromas [26-28]. Odor-active compounds in wine headspace must be extracted quickly and efficiently in order to minimize the effects of oxidation on the wine aroma profile. In this research, a SPME 50/30 $\mu$ m divinylbenzene (DVB)/Carboxen/polydimethylsiloxane (PDMS) coating was suitable for extraction of a wide variety of aroma volatiles including alcohols, esters, aldehydes and ketones, phenolics, and acids. Ethanol being the most prevalent in headspace did not outcompete volatile aromas for SPME sorption sites.

Simultaneous sensory and chemical analyses of white wine aroma was facilitated by the use of GC-MS-O. The advantage of using olfactometry $(\mathrm{O})$ simultaneously with chemical detection is the ability to focus on selected fewer aroma-causing compounds present in a very complex mixture of the wine headspace matrix. A sole focus on chemical analyses can preclude finding the aroma-defining volatile compounds in wine.

Grape sugar content ( ${ }^{\circ}$ Brix) varies depending on the species, variety, maturity (ripening), and health of the fruit [10]. Cultivars of European Vitis vinifera generally accumulate sugar at a concentration of $20 \%$ or more at maturity [29]. The cold-hardy cultivars Brianna and Frontenac gris pedigree includes $V$. riparia, $V$. labrusca, and $V$. vinifera $[30,31]$. Brianna, in particular, is often harvested at a lower "Brix to avoid "foxy" flavors. Sugar is added (chaptalization) to the juice to develop the $10-12 \%$ alcohol content typical of most still (non-sparkling) table wines [32]. The effects of sugar 
content and ethanol concentrations on the sensory attributes of young and aged sweet wines is found elsewhere [33,34]. However, there are few intervention options for enhancing the desired aromas. Thus, wine cold-hardy white wines produced from European/native N. American cultivars such as Brianna and Frontenac gris need to be "farmed for flavor." This means that growers should consider an optimal flavor profile as a harvest parameter, in addition to the ${ }^{\circ} \mathrm{Brix}, \mathrm{pH}$, and TA.

Grapes produce few aldehydes significant in varietal aromas. This may result from their reduction to alcohols during primary fermentation. Of the aldehydes not metabolized during primary fermentation, C-6 aldehydes appear to be the most noteworthy [35]. These aldehydes are responsible for the grassy to herbaceous odor associated with certain grape varieties or with wines made from immature grapes. They appear to be formed during crushing by the enzymatic oxidation of grape lipids [4]. Most aldehydes found in wine are created during processing or fermentation or are extracted from oak cooperage [32].

Likewise, few ketones are found in grapes. The norisoprenoid ketones (i.e., beta-damascenone, alpha-ionone, and beta-ionone) are persistent throughout fermentation [32]. The "apple, rose, honey" aroma of beta-damascenone [7] and low odor threshold [24] imply that it is important in the aroma of several grape varieties including "Chardonnay" [36] and "Riesling" [37]. The "seaweed, violet, flower, raspberry" aroma of beta-ionone [7], along with beta-damascenone, are important in the aroma of several red grape varieties [38]. Other ketones that are generated by fungal metabolism or produced during fermentation and acetals produced during aging and distillation will not be discussed in this research.

Of all the aromatic constituents of wine, esters are the most abundant. Most of these esters are found only in trace amounts and have either low volatility or non-distinct odors, and their importance to wine fragrance is often discounted. The more common esters such as acetate esters are derived from acetic acid and fusel alcohols, and the ethyl esters are formed between ethanol and fatty acids or nonvolatile, fixed organic acids. The fruity aromas are important in the aroma profile of young white wines [39]; however, the esters to the aromas of red wines is less understood.

Terpenes are an important group of aromatic compounds characterizing the aromas of "flower and lavender" (linalool), "rose and geranium" (geraniol), "sweet" (nerol), "oil, anise, mint" (alpha-terpineol), and "hyacinth" (hotrienol) [7]. Terpenes are responsible for the fragrance of herb-flavored wines such as vermouth and fruit-flavored wines. In addition, terpenes also characterize some wine grape cultivars, most notably the "Muscat" and "Riesling" families [40].

Pyrazines are important to the characteristic varietal aromas of several cultivars [41]. Ethyl 3-mercaptopropionate is an important compound suspected to be the "foxy" odor of some $V$. labrusca varieties [42]. Most thiols generate off-odors, and only a few contribute to the characteristic varietal aroma of wine grape cultivars. These are 4-mercapto-4-methylpentan-2-ol ("floral, lemon grapefruit") [24] and 3-mercaptohexan-1-ol ("grapefruit") [43]. Both compounds are important in the varietal character of "Sauvignon Blanc" [43]. A key aroma important in "Scheurebe" is 4-mercapto-4-methylpentan-2-ol [44].

Despite the information available on volatile wine odor-active compounds and their sensory perceptions, experienced tasters are not always able to determine the grape variety (Vinifera), even when $100 \%$ of the wine is made from that cultivar [45]. A review of wine aroma in grapes is provided elsewhere [46]. The question remains if these new cold-hardy cultivars produce a distinct varietal aroma in white wines. This research adds a valuable initial report on white wine aromas from Brianna and Frontenac gris grapes. To date, the only other published research on cold-hardy wine aromas pertains to red wines [47-50] and white wines [51]. Therefore, this research serves as a starting point for determining the odor-active compounds in Brianna and Frontenac gris cold-hardy wines. At this (screening) stage, using one panelist achieved the stated aims, i.e., preliminarily characterized odor active compounds. This information should be used for follow-up studies as a starting point for proper experimental design. This relatively low number of publications on cold-hardy wine varieties is significant compared with active research in Vinifera [52-62]. 
Results (obtained with GC-MS-O approach) from this research could be used to inform cold-hardy grape growers on "farming for flavor." A shift of the aroma profile from "fruity 1" to "rotten eggs, sulfury" to "rose 1" was observed in wines made from Frontenac gris harvested at 19.5, 23.1, and 23.6 ${ }^{\circ}$ Brix, respectively (Figure 3). The must was not submitted to cold-settling and might be a major reason for the "sulfury, rotten egg" odors found in the research wines. In addition, a shift of the aroma profile from "cotton candy" to "banana" to "floral" to "butterscotch" was observed in wines that were made from Brianna grapes harvested at 15.4, 17.6, 18.6, and $19.6^{\circ}$ Brix, respectively (Figure 4).

Similar shifts of actual flavor and aroma of wines made from Brianna were also observed during tasting sessions at conferences for wine industry professionals. Results from the lay audiences' flavor and aroma descriptors (Figure 5) also indicate a shift with harvest date and associated ${ }^{\circ}$ Brix. The most obvious change at the late harvest date is the use of the term "foxy", a negative characteristic associated with V. labrusca-based wines. There was also a decrease in the use of "acidity," although "citrus" was still mentioned. Additional flavor descriptors that had a higher incidence in the late harvested wine included "bitter", "floral", and "pineapple". The lay audiences' perceptions of the Brianna wine detected some of the "sulfur", "dirty", "musty" aromas but at a very low incidence.

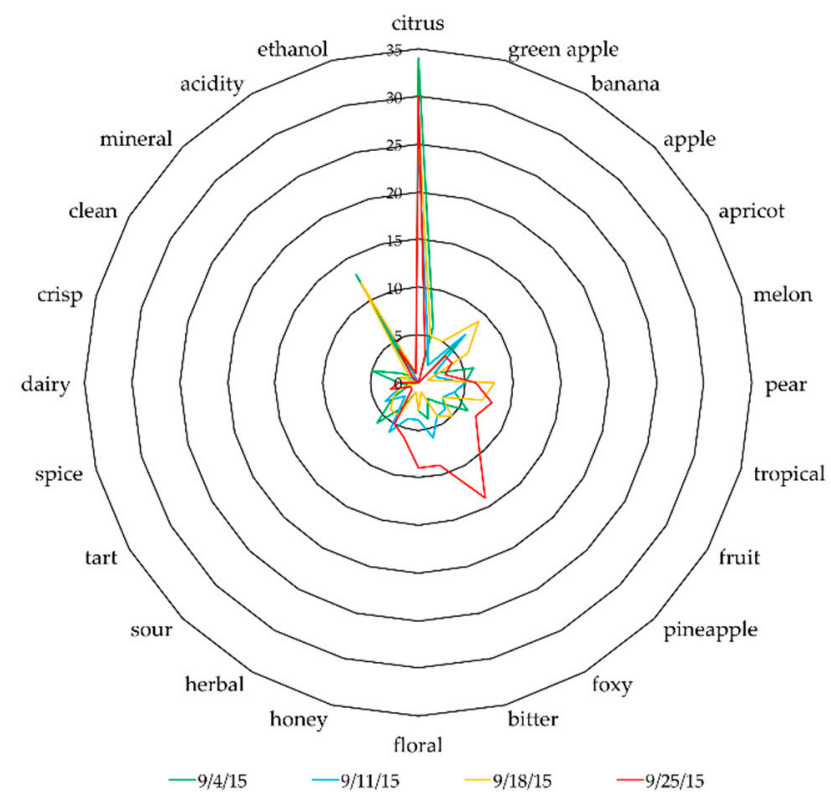

Figure 5. A spiderplot indicating a shift of flavor and aroma descriptors of Brianna wines, that were made from grapes harvested from 4 September to 25 September, from the wine tasting panels generated by lay audiences at conferences for wine industry professionals. A shift of flavor and aroma descriptors is associated with the increase in "Brix and appearance of "foxy", a negative characteristic associated with $V$. labrusca-based wines at the latest harvest date.

This research will help support the sustainable development of cold-hardy grape growing and the winemaking industry in Midwest U.S by providing a baseline for viticultural and wine-making practices. The next logical step would be to relate aroma-active compounds with sensory attributes by means of pattern recognition techniques that use multivariate statistical tests such, as principal component analysis, cluster analysis, or even partial least square (PLS) algorithms as previously described $[63,64]$. It is also possible to use the volatile data obtained by GC to construct odorant series with a given odor activity value for comparison purposes with sensorial data as in References [26-28,65-67].

More research is warranted on the aromas of white wines produced from cold-hardy cultivars. Several recommendations could be made including repeated studies involving a greater number of growing seasons and eventually developing consistent regional wine styles. This could include linking the sensory characteristics such as color, body and mouthfeel [68], and aroma. 


\section{Conclusions}

This is the first report of white wine aromas from cold-hardy Brianna and Frontenac gris by GC-MS-O. Findings from this research support the hypothesis that aroma profiles of Brianna and Frontenac gris wines can be influenced by harvesting the grapes at different stages of ripening. Evaluation of the respective cultivar wines from different harvest dates but the same alcohol content allowed the detection of over 30 odor-active compounds in the wine headspace for both Brianna and Frontenac gris. The particular wine aroma profile changed depending on the time of harvest and grape maturity. Aromas in Brianna wines developed from "cotton candy" and "floral" to "banana" and "butterscotch" and then finally to "honey", "caramel", and an "unknown neutral" aroma. Over 68\% of the variation in harvest time was correlated with key odor-active compounds. Aromas in Frontenac gris wines changed from an "unknown neutral" aroma to "fruity" to "rose". Over $98 \%$ of the variation in harvest time was correlated with key odor-active compounds. Wine tasting data generated by wine industry professionals at conferences showed a shift in flavor and aroma descriptors for Brianna wines. The shift of flavor and aroma descriptors is associated with the increase in ${ }^{\circ}$ Brix and "foxy," a negative characteristic associated with $V$. labrusca-based wines at the latest harvest dates. This research provides both positive and negative aroma characteristics associated with increased ripeness and will help support the sustainable development of cold-hardy grape growing and the winemaking industry in Midwest U.S by providing a baseline for viticultural and wine-making practices.

Author Contributions: Conceptualization, S.R., M.D., A.F., and J.A.K.; methodology, S.R., D.G., and A.F.; winemaking, D.G.; lay sensory analysis, M.C. and A.F.; formal analysis, S.R.; investigation, S.R., M.T., M.D., A.F., M.C., and J.A.K.; writing-original draft preparation, S.R.; writing-review and editing, S.R., M.D., A.F., M.C., and J.A.K.; supervision, J.A.K. and M.D.; funding acquisition, J.A.K. and M.D.; visualization, S.R.; data curation, S.R. and J.A.K.

Funding: This research was funded by the United States Department of Agriculture's Special Crops Research Initiative Program of the National Institute for Food and Agriculture, grant number 2011-51181-30850, titled "Northern grapes: integrating viticulture, winemaking, and marketing of new cold-hardy cultivars supporting new and growing rural wineries". In addition, this project was partially supported by the Iowa Agriculture and Home Economics Experiment Station, Ames, Iowa. Project No. IOW05400 (Animal Production Systems: Synthesis of Methods to Determine Triple Bottom Line Sustainability from Findings of Reductionist Research) is sponsored by Hatch Act and State of Iowa funds.

Conflicts of Interest: The authors declare no conflict of interest. The funders had no role in the design of the study; in the collection, analyses, or interpretation of data; in the writing of the manuscript; and in the decision to publish the results. 


\section{Appendix A}

Table A1. Summary of identified aromas and associated compounds in the headspace of wines made from Brianna and Frontenac gris cold-hardy grapes. Percent match to NIST 11 mass spectral library was equal or greater than $80 \%$.

\begin{tabular}{|c|c|c|c|c|c|c|c|c|}
\hline $\begin{array}{l}\text { Event } \\
\text { Number }\end{array}$ & Aroma Descriptor & $\begin{array}{l}\text { Weighted } \\
\text { Intensity }\end{array}$ & $\begin{array}{l}\text { Retention } \\
\text { time (min) }\end{array}$ & $\begin{array}{l}\text { Aroma Event } \\
\text { Width (min) }\end{array}$ & OD * & $\begin{array}{l}\text { Mass Spectral Library } \\
\text { Identification }\end{array}$ & $\begin{array}{l}\text { Chemical } \\
\text { Abstracts } \\
\text { Service } \\
\text { Number }\end{array}$ & $\begin{array}{c}\text { Significant Ions (Number of Ions } \\
\text { Listed: Ions Listed in the Order } \\
\text { of Intensity) }\end{array}$ \\
\hline \multicolumn{9}{|c|}{ Variety: Brianna; Harvest Date: 4 September 2015; Sample Number: 1} \\
\hline 1 & Rotten eggs & 79 & 2.54 & 0.03 & 32 & Not detected & & \\
\hline 2 & Alcoholic & 307 & 3.2 & 0.19 & 32 & Ethanol & $64-17-5$ & 5: 4345604244 \\
\hline 3 & Butterscotch 2 & 115 & 4.81 & 0.08 & 32 & Ethyl lactate & $97-64-3$ & 7: 457543464761103 \\
\hline 4 & Body odor & 118 & 5.31 & 0.08 & 32 & Isobutyl alcohol & $78-83-1$ & 11: 4142397457597340375852 \\
\hline 5 & Honey, caramel & 256 & 5.75 & 0.11 & 32 & Ethyl isobutyrate & $97-62-1$ & 10: 7189604110173102905988 \\
\hline 6 & Floral, fruity & 312 & 6.91 & 0.08 & 32 & Ethyl butyrate & $105-54-4$ & 2: 107108 \\
\hline 7 & Solvent & 302 & 7.2 & 0.07 & 32 & Unknown & & \\
\hline 8 & Over ripe fruit 1 & 283 & 7.56 & 0.09 & 32 & Isoamyl alcohol & $123-51-3$ & $\begin{array}{c}\text { 15: } 6073418743554257396169 \\
59995058\end{array}$ \\
\hline 9 & Over ripe fruit 2 & 311 & 8 & 0.16 & 32 & Isoamyl alcohol & $123-51-3$ & 0 \\
\hline 10 & Fruity 2 & 177 & 8.27 & 0.08 & 32 & Ethyl isovalerate & $108-64-5$ & 0 \\
\hline 11 & Banana & 273 & 9.04 & 0.08 & 32 & Isoamyl acetate & $123-92-2$ & $\begin{array}{c}20: 9192122655139779363103 \\
1045062526479663875102\end{array}$ \\
\hline 12 & Unknown pleasant & 111 & 11.32 & 0.09 & 32 & Unknown & & \\
\hline 13 & Fruity 3 & 369 & 12.22 & 0.1 & 32 & Ethyl hexanoate & $123-66-0$ & 4: 74718759 \\
\hline 14 & Garlic & 63 & 12.83 & 0.11 & 32 & Not detected & & \\
\hline 15 & Unknown neutral 2 & 98 & 15.18 & 0.09 & 32 & Unknown & & \\
\hline 16 & Rose & 158 & 15.91 & 0.16 & 32 & Unknown & & \\
\hline 17 & Matchstick & 92 & 16.7 & 0.08 & 32 & Unknown & & \\
\hline 18 & Cut grass & 333 & 17.06 & 0.2 & 32 & Ethyl octanoate & $106-32-1$ & $\begin{array}{c}\text { 17: } 1081071507743791098090 \\
51785350398962105\end{array}$ \\
\hline 19 & Barnyard & 122 & 18.43 & 0.16 & 32 & 4-methylphenyl acetate & $140-39-6$ & 10: 437111688418942574470 \\
\hline 20 & Mint & 67 & 19.3 & 0.07 & 32 & Methyl salicylate & $119-36-8$ & 8: 57852121128397141113 \\
\hline 21 & Unknown neutral 3 & 264 & 19.97 & 0.07 & 32 & Phenethyl alcohol & $60-12-8$ & $\begin{array}{c}\text { 20: } 88101155731577043554160 \\
\quad 6189695771115143834285\end{array}$ \\
\hline 22 & Strawberry 1 & 309 & 21.52 & 0.35 & 32 & Ethyl decanoate & $110-38-3$ & 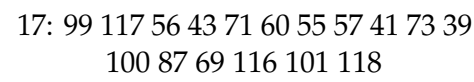 \\
\hline 23 & Strawberry 2 & 406 & 22.09 & 0.08 & 32 & Octanoic acid & $124-07-2$ & 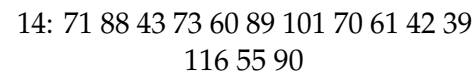 \\
\hline
\end{tabular}


Table A1. Cont.

\begin{tabular}{|c|c|c|c|c|c|c|c|c|}
\hline $\begin{array}{l}\text { Event } \\
\text { Number }\end{array}$ & Aroma Descriptor & $\begin{array}{l}\text { Weighted } \\
\text { Intensity }\end{array}$ & $\begin{array}{l}\text { Retention } \\
\text { time (min) }\end{array}$ & $\begin{array}{l}\text { Aroma Event } \\
\text { Width (min) }\end{array}$ & OD * & $\begin{array}{l}\text { Mass Spectral Library } \\
\text { Identification }\end{array}$ & $\begin{array}{l}\text { Chemical } \\
\text { Abstracts } \\
\text { Service } \\
\text { Number }\end{array}$ & $\begin{array}{c}\text { Significant Ions (Number of Ions } \\
\text { Listed: Ions Listed in the Order } \\
\text { of Intensity) }\end{array}$ \\
\hline \multicolumn{9}{|c|}{ Variety: Brianna; Harvest Date: 04 September 2015; Sample Number: 2} \\
\hline 1 & Rotten eggs & 70 & 2.54 & 0.03 & 32 & Not detected & & \\
\hline 2 & Alcoholic & 383 & 3.2 & 0.19 & 32 & Ethanol & $64-17-5$ & $\begin{array}{c}\text { 15: } 4546434742414440334877 \\
49397834\end{array}$ \\
\hline 3 & Butterscotch 2 & 106 & 4.81 & 0.08 & 32 & Unknown & & \\
\hline 4 & Body odor & 123 & 5.31 & 0.45 & 32 & Isobutyl alcohol & $78-83-1$ & $\begin{array}{c}\text { 18: } 4341423339745556574059 \\
44533750544952\end{array}$ \\
\hline 5 & Honey, caramel & 255 & 5.67 & 1.38 & 32 & Ethyl isobutyrate & $97-62-1$ & 5: 71116738889 \\
\hline 6 & Solvent & 320 & 7.25 & 0.01 & 32 & Unknown & & \\
\hline 7 & Over ripe fruit 1 & 2 & 7.52 & 0.04 & 1 & Isoamyl alcohol & $123-51-3$ & $\begin{array}{c}\text { 20: } 5570424339456971464440 \\
385150476037675273\end{array}$ \\
\hline 8 & Over ripe fruit 2 & 2 & 7.99 & 0.06 & 1 & Isoamyl alcohol & $123-51-3$ & $\begin{array}{c}\text { 20: } 5570424339456971464440 \\
385150476037675273\end{array}$ \\
\hline 9 & Over ripe fruit 2 & 1 & 8.23 & 0.03 & 1 & Ethyl isovalerate & $108-64-5$ & 6: 8885606111587 \\
\hline 10 & Banana & 2 & 9.04 & 0.03 & 1 & Isoamyl acetate & $123-92-2$ & $\begin{array}{c}\text { 19: } 4370558761424173693944 \\
58885753855411540\end{array}$ \\
\hline 11 & Unknown pleasant & 3 & 11.32 & 0.04 & 2 & Unknown & & \\
\hline 12 & Fruity 3 & 360 & 12.25 & 0.03 & 32 & Ethyl hexanoate & $123-66-0$ & $\begin{array}{c}\text { 20: } 88994310160707173614155 \\
\quad 421154539876911789100\end{array}$ \\
\hline 13 & Garlic & 0 & 12.82 & 0.03 & 1 & Not detected & & \\
\hline 14 & Unknown neutral 2 & 34 & 15.17 & 0.08 & 32 & Unknown & & \\
\hline 15 & Rose & 1 & 15.94 & 0.03 & 1 & Unknown & & \\
\hline 16 & Matchstick & 2 & 16.69 & 0.02 & 2 & Unknown & & \\
\hline 17 & Cut grass & 7 & 17.02 & 0.08 & 2 & Ethyl octanoate & $106-32-1$ & $\begin{array}{c}20: 8810112757737060554161 \\
43129115894269458314339\end{array}$ \\
\hline 18 & Barnyard & 2 & 18.41 & 0.09 & 2 & Unknown & & \\
\hline 19 & Mint & 1 & 19.38 & 0.04 & 1 & Unknown & & \\
\hline 20 & Unknown neutral 3 & 322 & 20 & 0.05 & 32 & Phenethyl alcohol & $60-12-8$ & $\begin{array}{c}\text { 20: } 91921226539517763937889 \\
103123104506290526466\end{array}$ \\
\hline 21 & Cotton candy & 13 & 21.42 & 0.07 & 2 & Ethyl decanoate & $110-38-3$ & $\begin{array}{c}\text { 20: } 88101155731577043554160 \\
\quad 6189695771115143834285\end{array}$ \\
\hline 22 & Strawberry 2 & 3 & 21.98 & 0.24 & 1 & Octanoic acid & $124-07-2$ & $\begin{array}{c}20: 607343101415585848769 \\
1156139455774836797102\end{array}$ \\
\hline
\end{tabular}


Table A1. Cont.

\begin{tabular}{|c|c|c|c|c|c|c|c|c|}
\hline $\begin{array}{l}\text { Event } \\
\text { Number }\end{array}$ & Aroma Descriptor & $\begin{array}{l}\text { Weighted } \\
\text { Intensity }\end{array}$ & $\begin{array}{l}\text { Retention } \\
\text { time (min) }\end{array}$ & $\begin{array}{l}\text { Aroma Event } \\
\text { Width (min) }\end{array}$ & OD * & $\begin{array}{l}\text { Mass Spectral Library } \\
\text { Identification }\end{array}$ & $\begin{array}{l}\text { Chemical } \\
\text { Abstracts } \\
\text { Service } \\
\text { Number }\end{array}$ & $\begin{array}{c}\text { Significant Ions (Number of Ions } \\
\text { Listed: Ions Listed in the Order } \\
\text { of Intensity) }\end{array}$ \\
\hline 23 & Unknown neutral 4 & 1 & 24.45 & 0.05 & 1 & Unknown & & \\
\hline 24 & Unknown neutral 4 & 2 & 24.74 & 0.04 & 1 & Unknown & & \\
\hline 25 & Unknown neutral 5 & 1 & 25.2 & 0.05 & 1 & Decanoic acid & $334-48-5$ & $\begin{array}{c}\text { 20: } 736012971574155436987 \\
11583618439143741125642\end{array}$ \\
\hline \multicolumn{9}{|c|}{ Variety: Brianna; Harvest Time: 11 September 2015; Sample Number: 1} \\
\hline 1 & Rotten eggs & 106 & 2.54 & 0.03 & 32 & Not detected & & \multirow{7}{*}{$\begin{array}{c}\text { 20: } 4546434247414433404877 \\
4939617834535538165 \\
2: 4575 \\
\text { 20: } 4341423339745556574059 \\
387344533750517234 \\
\text { 10: } 4371116418873894272101 \\
\text { 17: } 718843416089421013961 \\
1167211790403847\end{array}$} \\
\hline 2 & Alcoholic & 420 & 3.2 & 0.19 & 32 & Ethanol & $64-17-5$ & \\
\hline 3 & Butterscotch 2 & 71 & 4.81 & 0.08 & 32 & Ethyl lactate & $97-64-3$ & \\
\hline 4 & Body odor & 95 & 5.31 & 0.08 & 32 & Isobutyl alcohol & 78-83-1 & \\
\hline 5 & Honey, caramel & 355 & 5.75 & 0.11 & 32 & Ethyl isobutyrate & $97-62-1$ & \\
\hline 6 & Floral, fruity & 361 & 6.91 & 0.08 & 32 & Ethyl butyrate & $105-54-4$ & \\
\hline 7 & Solvent & 337 & 7.2 & 0.07 & 32 & Unknown & & \\
\hline 8 & Over ripe fruit 1 & 345 & 7.56 & 0.09 & 32 & Isoamyl alcohol & $123-51-3$ & \multirow{4}{*}{$\begin{array}{c}\text { 20: } 5570414243456971464440 \\
\quad 385460376735526263 \\
\text { 20: } 5570414243456971464440 \\
\quad 385460376735526263 \\
\text { 9: } 88856061871155910386 \\
\text { 19: } 4370558761414273693971 \\
5688445857855340\end{array}$} \\
\hline 9 & Over ripe fruit 2 & 373 & 8 & 0.16 & 32 & Isoamyl alcohol & $123-51-3$ & \\
\hline 10 & Fruity 2 & 91 & 8.27 & 0.08 & 32 & Ethyl isovalerate & $108-64-5$ & \\
\hline 11 & Banana & 308 & 9.04 & 0.08 & 32 & Isoamyl acetate & $123-92-2$ & \\
\hline 12 & Unknown pleasant & 55 & 11.32 & 0.09 & 32 & Unknown & & \multirow{6}{*}{ 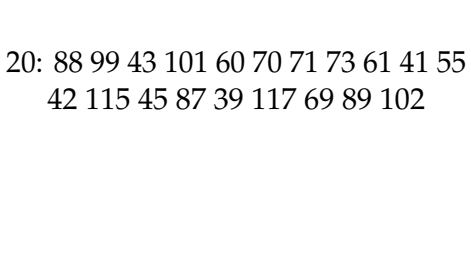 } \\
\hline 13 & Fruity 3 & 394 & 12.22 & 0.1 & 32 & Ethyl hexanoate & $123-66-0$ & \\
\hline 14 & Garlic & 40 & 12.83 & 0.11 & 32 & Not detected & & \\
\hline 15 & Unknown neutral 2 & 57 & 15.18 & 0.09 & 32 & Unknown & & \\
\hline 16 & Rose & 123 & 15.91 & 0.16 & 32 & Unknown & & \\
\hline 17 & Matchstick & 39 & 16.7 & 0.08 & 32 & Unknown & & \\
\hline 18 & Cut grass & 423 & 17.06 & 0.2 & 32 & Ethyl octanoate & $106-32-1$ & \multirow[t]{2}{*}{$\begin{array}{c}\text { 20: } 8810112757737055604161 \\
43129115428969458314339\end{array}$} \\
\hline 19 & Barnyard & $\begin{array}{l}40 \\
49\end{array}$ & 18.43 & 0.16 & 32 & Not detected & & \\
\hline
\end{tabular}


Table A1. Cont.

\begin{tabular}{|c|c|c|c|c|c|c|c|c|}
\hline $\begin{array}{l}\text { Event } \\
\text { Number }\end{array}$ & Aroma Descriptor & $\begin{array}{l}\text { Weighted } \\
\text { Intensity }\end{array}$ & $\begin{array}{l}\text { Retention } \\
\text { time (min) }\end{array}$ & $\begin{array}{l}\text { Aroma Event } \\
\text { Width (min) }\end{array}$ & OD * & $\begin{array}{l}\text { Mass Spectral Library } \\
\text { Identification }\end{array}$ & $\begin{array}{c}\text { Chemical } \\
\text { Abstracts } \\
\text { Service } \\
\text { Number }\end{array}$ & $\begin{array}{c}\text { Significant Ions (Number of Ions } \\
\text { Listed: Ions Listed in the Order } \\
\text { of Intensity) }\end{array}$ \\
\hline 21 & Unknown neutral 3 & 345 & 19.97 & 0.07 & 32 & Phenethyl alcohol & $60-12-8$ & $\begin{array}{c}\text { 20: } 91921226539637751937889 \\
103123104506252906441\end{array}$ \\
\hline 22 & Strawberry 1 & 307 & 21.49 & 0.38 & 32 & Ethyl decanoate & $110-38-3$ & $\begin{array}{c}\text { 20: } 88101155157737055414360 \\
\quad 6169891155771143834245\end{array}$ \\
\hline 23 & Strawberry 2 & 498 & 22.01 & 0.16 & 32 & Octanoic acid & $124-07-2$ & $\begin{array}{c}\text { 20: } 60734355411018584876961 \\
\quad 3911545425756748382\end{array}$ \\
\hline 24 & Tomato 1 & 63 & 24.32 & 0.02 & 32 & Not detected & & \\
\hline 25 & Unknown neutral 4 & 162 & 24.78 & 0.02 & 32 & Unknown & & \\
\hline 26 & Unknown neutral 5 & 94 & 25.27 & 0.02 & 32 & Decanoic acid & $334-48-5$ & $\begin{array}{c}\text { 19: } 736012941555743716987 \\
115836117242841433956\end{array}$ \\
\hline \multicolumn{9}{|c|}{ Variety: Brianna; Harvest Time: 11 September 2015; Sample Number: 2} \\
\hline 1 & Rotten eggs & 54 & 2.54 & 0.03 & 32 & Not detected & & \\
\hline 2 & Alcoholic & 420 & 3.2 & 0.19 & 32 & Ethanol & $64-17-5$ & $\begin{array}{c}\text { 17: } 4546434247414433404877 \\
493961917895\end{array}$ \\
\hline 3 & Butterscotch 2 & 71 & 4.81 & 0.08 & 32 & Unknown & & \\
\hline 4 & Body odor & 95 & 5.31 & 0.08 & 32 & Ethyl propionate & $105-37-3$ & \\
\hline 5 & Honey, caramel & 355 & 5.75 & 0.11 & 32 & Ethyl isobutyrate & $97-62-1$ & 6: 71116883373117 \\
\hline 6 & Floral, fruity & 361 & 6.91 & 0.08 & 32 & Unknown & & \\
\hline 7 & Solvent & 337 & 7.2 & 0.07 & 32 & Ethyl butyrate & $105-54-4$ & $\begin{array}{c}\text { 14: } 718843734189101706172 \\
116576937\end{array}$ \\
\hline 8 & Over ripe fruit 1 & 345 & 7.56 & 0.09 & 32 & Unknown & & \\
\hline 9 & Over ripe fruit 2 & 373 & 8 & 0.16 & 32 & Isoamyl alcohol & $123-51-3$ & 10: 70424339444651593749 \\
\hline 10 & Fruity 2 & 91 & 8.27 & 0.08 & 32 & Not detected & & \\
\hline 11 & Banana & 308 & 9.04 & 0.08 & 32 & Isoamyl acetate & $123-92-2$ & $\begin{array}{c}20: 4370558761414273693988 \\
585644855753455440\end{array}$ \\
\hline 12 & Unknown pleasant & 55 & 11.32 & 0.09 & 32 & Unknown & & \\
\hline 13 & Fruity 3 & 394 & 12.22 & 0.1 & 32 & Unknown & & \\
\hline 14 & Garlic & 40 & 12.83 & 0.11 & 32 & Not detected & & \\
\hline 15 & Unknown neutral 2 & 57 & 15.18 & 0.09 & 32 & Ethyl heptanoate & $106-30-9$ & 10: 88113101848774698389102 \\
\hline 16 & Rose & 123 & 15.91 & 0.16 & 32 & Unknown & & \\
\hline 17 & Matchstick & 39 & 16.7 & 0.08 & 32 & Unknown & & \\
\hline 18 & Cut grass & 423 & 17.06 & 0.2 & 32 & Ethyl octanoate & $106-32-1$ & $\begin{array}{c}\text { 20: } 8810112757737055604161 \\
43129115894269143834539\end{array}$ \\
\hline
\end{tabular}


Table A1. Cont.

\begin{tabular}{|c|c|c|c|c|c|c|c|c|}
\hline $\begin{array}{l}\text { Event } \\
\text { Number }\end{array}$ & Aroma Descriptor & $\begin{array}{l}\text { Weighted } \\
\text { Intensity }\end{array}$ & $\begin{array}{l}\text { Retention } \\
\text { time (min) }\end{array}$ & $\begin{array}{l}\text { Aroma Event } \\
\text { Width (min) }\end{array}$ & OD * & $\begin{array}{l}\text { Mass Spectral Library } \\
\text { Identification }\end{array}$ & $\begin{array}{l}\text { Chemical } \\
\text { Abstracts } \\
\text { Service } \\
\text { Number }\end{array}$ & $\begin{array}{c}\text { Significant Ions (Number of Ions } \\
\text { Listed: Ions Listed in the Order } \\
\text { of Intensity) }\end{array}$ \\
\hline 19 & Barnyard & 40 & 18.43 & 0.16 & 32 & Unknown & & \\
\hline 20 & Mint & 49 & 19.3 & 0.07 & 32 & Unknown & & \\
\hline 21 & Unknown neutral 3 & 345 & 19.97 & 0.07 & 32 & Unknown & & \\
\hline 22 & Strawberry 1 & 307 & 21.49 & 0.38 & 32 & Unknown & & \\
\hline 23 & Strawberry 2 & 498 & 22.01 & 0.16 & 32 & Octanoic acid & $124-07-2$ & $\begin{array}{c}20: 607343554110185848769 \\
115614539425756748382\end{array}$ \\
\hline 24 & Tomato 1 & 63 & 24.32 & 0.02 & 32 & Diphenylmethane & $101-81-5$ & 13: $\begin{array}{c}1671681651521691667663 \\
1411281645078\end{array}$ \\
\hline 25 & Unknown neutral 4 & 162 & 24.78 & 0.02 & 32 & Unknown & & \\
\hline 26 & Unknown neutral 5 & 94 & 25.27 & 0.02 & 32 & Decanoic acid & $334-48-5$ & $\begin{array}{c}\text { 19: } 73601295541577143876983 \\
115618439744214370\end{array}$ \\
\hline \multicolumn{9}{|c|}{ Variety: Brianna; Harvest Time: 18 September 2015; Sample Number: 1} \\
\hline 1 & Rotten eggs & 87 & 2.54 & 0.03 & 32 & Not detected & & \\
\hline 2 & Alcoholic & 411 & 3.2 & 0.19 & 32 & Ethanol & $64-17-5$ & $\begin{array}{c}\text { 17: } 4546434247414433404877 \\
499155785192\end{array}$ \\
\hline 3 & Butterscotch 2 & 109 & 4.81 & 0.08 & 32 & Unknown & & \\
\hline 4 & Body odor & 42 & 5.31 & 0.08 & 32 & Isobutyl alcohol & $78-83-1$ & $\begin{array}{c}\text { 13: } 4341423974555657385344 \\
7337\end{array}$ \\
\hline 5 & Honey, caramel & 468 & 5.75 & 0.11 & 32 & Ethyl isobutyrate & $97-62-1$ & 10: 437188411165573423972 \\
\hline 6 & Floral, fruity & 472 & 6.91 & 0.08 & 32 & Ethyl butyrate & $105-54-4$ & $\begin{array}{c}\text { 16: } 71884373604189101427061 \\
3955403862\end{array}$ \\
\hline 7 & Solvent & 425 & 7.2 & 0.07 & 32 & Unknown & & \\
\hline 8 & Over ripe fruit 1 & 455 & 7.56 & 0.09 & 32 & Unknown & & \\
\hline 9 & Over ripe fruit 2 & 360 & 8 & 0.16 & 32 & Unknown & & \\
\hline 10 & Fruity 2 & 117 & 8.27 & 0.08 & 32 & Isoamyl alcohol & $123-51-3$ & $\begin{array}{c}\text { 13: } 5570424339454644534073 \\
6662\end{array}$ \\
\hline 11 & Banana & 467 & 9.04 & 0.08 & 32 & Isoamyl acetate & $123-92-2$ & $\begin{array}{c}\text { 20: } 4370558761414273693971 \\
448856585785534554\end{array}$ \\
\hline 12 & Unknown pleasant & 71 & 11.32 & 0.09 & 32 & Unknown & & \\
\hline 13 & Fruity 3 & 506 & 12.22 & 0.1 & 32 & Ethyl hexanoate & $123-66-0$ & $\begin{array}{c}\text { 20: } 88994310160707173416155 \\
421154539876911789100\end{array}$ \\
\hline 14 & Garlic & 106 & 12.83 & 0.11 & 32 & Not detected & & \\
\hline 15 & Unknown neutral 2 & 34 & 15.18 & 0.09 & 32 & Rose oxide & $16409-43$ & 9: 139698315414084855377 \\
\hline
\end{tabular}


Table A1. Cont.

\begin{tabular}{|c|c|c|c|c|c|c|c|c|}
\hline $\begin{array}{l}\text { Event } \\
\text { Number }\end{array}$ & Aroma Descriptor & $\begin{array}{l}\text { Weighted } \\
\text { Intensity }\end{array}$ & $\begin{array}{l}\text { Retention } \\
\text { time (min) }\end{array}$ & $\begin{array}{l}\text { Aroma Event } \\
\text { Width (min) }\end{array}$ & OD * & $\begin{array}{l}\text { Mass Spectral Library } \\
\text { Identification }\end{array}$ & $\begin{array}{c}\text { Chemical } \\
\text { Abstracts } \\
\text { Service } \\
\text { Number }\end{array}$ & $\begin{array}{c}\text { Significant Ions (Number of Ions } \\
\text { Listed: Ions Listed in the Order } \\
\text { of Intensity) }\end{array}$ \\
\hline 16 & $\begin{array}{l}\text { Unknown } \\
\text { unpleasant }\end{array}$ & 71 & 15.69 & 0.07 & 32 & Unknown & & \\
\hline 17 & Rose & 129 & 15.91 & 0.16 & 32 & Unknown & & \\
\hline 18 & Matchstick & 41 & 16.7 & 0.08 & 32 & Unknown & & \\
\hline 19 & Cut grass & 500 & 17.06 & 0.2 & 32 & Ethyl octanoate & 106-32-1 & $\begin{array}{c}\text { 20: } 8810112757737055604161 \\
43129115428969143458339\end{array}$ \\
\hline 20 & Barnyard & 11 & 18.43 & 0.16 & 32 & Unknown & & \\
\hline 21 & Mint & 26 & 19.3 & 0.07 & 32 & Methyl salicylate & $119-36-8$ & 5: 1201529265149 \\
\hline 22 & Unknown neutral 3 & 363 & 19.97 & 0.07 & 32 & Phenethyl alcohol & $60-12-8$ & $\begin{array}{c}\text { 20: } 919212265779351396378 \\
1031045062905279415375\end{array}$ \\
\hline 23 & Strawberry 1 & 382 & 21.49 & 0.38 & 32 & Ethyl decanoate & $110-38-3$ & $\begin{array}{c}\text { 20: } 88101155157737055414360 \\
\quad 6169895711571143834285\end{array}$ \\
\hline 24 & Strawberry 2 & 579 & 22.01 & 0.16 & 32 & Octanoic acid & 124-07-2 & $\begin{array}{c}20: 607343101554185848769 \\
115396145425756748382\end{array}$ \\
\hline 25 & Tomato 1 & 73 & 24.32 & 0.02 & 32 & Unknown & & \\
\hline 26 & Unknown neutral 4 & 154 & 24.78 & 0.02 & 32 & Unknown & & \\
\hline 27 & Unknown neutral 5 & 94 & 25.27 & 0.02 & 32 & Decanoic acid & $334-48-5$ & $\begin{array}{c}\text { 20: } 73601295557417143698783 \\
115110618411274567053\end{array}$ \\
\hline \multicolumn{9}{|c|}{ Variety: Brianna; Harvest Time: 18 September 2015; Sample Number: 2} \\
\hline 1 & Rotten eggs & 46 & 2.54 & 0.03 & 32 & Not detected & & \multirow[b]{2}{*}{$\begin{array}{c}\text { 18: } 4546434247414433404877 \\
493955918497104\end{array}$} \\
\hline 2 & Alcoholic & 4 & 3.2 & 0.19 & 1 & Ethanol & $64-17-5$ & \\
\hline 3 & Fruity 1 & 21 & 4.2 & 0.38 & 32 & Not detected & & \multirow{3}{*}{$\begin{array}{c}2: 4575 \\
\text { 12: } 43414239745657405338 \\
4437\end{array}$} \\
\hline 4 & Butterscotch 2 & 18 & 4.81 & 0.08 & 32 & Ethyl lactate & $97-64-3$ & \\
\hline 5 & Body odor & 16 & 5.31 & 0.08 & 32 & Isobutyl alcohol & 78-83-1 & \\
\hline 6 & Honey, caramel & 6 & 6.1 & -0.24 & 1 & Not detected & & \multirow{7}{*}{$\begin{array}{c}\text { 10: } 70413945533858507287 \\
\text { 20: } 4370558761414273693971 \\
585644885753854540\end{array}$} \\
\hline 7 & Floral & 5 & 7.35 & -0.36 & 1 & Not detected & & \\
\hline 8 & Over ripe fruit 1 & 2 & 7.65 & -0.38 & 1 & Not detected & & \\
\hline 9 & Over ripe fruit 2 & 6 & 7.82 & 0.28 & 1 & Isoamyl alcohol & $123-51-3$ & \\
\hline 10 & Fruity 2 & 316 & 8.45 & -0.1 & 32 & Not detected & & \\
\hline 11 & Banana & 6 & 9.4 & -0.28 & 1 & Isoamyl acetate & $123-92-2$ & \\
\hline 12 & Unknown pleasant & 0 & 11.32 & 0.09 & 1 & Unknown & & \\
\hline
\end{tabular}


Table A1. Cont.

\begin{tabular}{|c|c|c|c|c|c|c|c|c|}
\hline $\begin{array}{l}\text { Event } \\
\text { Number }\end{array}$ & Aroma Descriptor & $\begin{array}{l}\text { Weighted } \\
\text { Intensity }\end{array}$ & $\begin{array}{l}\text { Retention } \\
\text { time (min) }\end{array}$ & $\begin{array}{l}\text { Aroma Event } \\
\text { Width (min) }\end{array}$ & OD * & $\begin{array}{l}\text { Mass Spectral Library } \\
\text { Identification }\end{array}$ & $\begin{array}{l}\text { Chemical } \\
\text { Abstracts } \\
\text { Service } \\
\text { Number }\end{array}$ & $\begin{array}{c}\text { Significant Ions (Number of Ions } \\
\text { Listed: Ions Listed in the Order } \\
\text { of Intensity) }\end{array}$ \\
\hline 13 & Garlic & 16 & 13.08 & -0.14 & 8 & Not detected & \multirow{8}{*}{$821-55-6$} & \multirow{8}{*}{$\begin{array}{c}\text { 14: } 5843715957142127858295 \\
113537254\end{array}$} \\
\hline 14 & Garlic & 239 & 13 & 0.07 & 32 & Not detected & & \\
\hline 15 & $\begin{array}{l}\text { Unknown } \\
\text { unpleasant }\end{array}$ & 193 & 15.65 & 0.15 & 32 & 2-Nonanone & & \\
\hline 16 & Rose & 1 & 16.43 & -0.36 & 1 & Unknown & & \\
\hline 17 & Cut grass & 6 & 17.09 & 0.17 & 1 & Unknown & & \\
\hline 18 & Barnyard & 1 & 18.43 & 0.16 & 1 & Not detected & & \\
\hline 19 & Mint & 28 & 19.3 & 0.07 & 32 & Not detected & & \\
\hline 20 & Fruity 4 & 28 & 19.71 & 0.01 & 32 & Unknown & & \\
\hline 21 & Unknown neutral 3 & 5 & 20.05 & -0.01 & 1 & Phenethyl alcohol & $60-12-8$ & \multirow{6}{*}{$\begin{array}{c}\text { 20: } 9192122657739517889103 \\
\text { 123 104506252 } 64387975120 \\
\text { 20: } 88101155157737055414360 \\
6169891155771143834285 \\
\text { 20: } 607355431014185848769 \\
115613945575674838253\end{array}$} \\
\hline 22 & Strawberry 1 & 320 & 21.5 & 0.37 & 32 & Ethyl decanoate & $110-38-3$ & \\
\hline 23 & Strawberry 2 & 422 & 22.05 & 0.12 & 32 & Octanoic acid & $124-07-2$ & \\
\hline 24 & Tomato 1 & 79 & 24.32 & 0.02 & 32 & Not detected & & \\
\hline 25 & Tomato 2 & 91 & 24.78 & 0.02 & 32 & Unknown & & \\
\hline 26 & Unknown neutral 5 & 146 & 25.27 & 0.02 & 32 & Unknown & & \\
\hline \multicolumn{9}{|c|}{ Variety: Brianna; Harvest Time: 25 September 2015; Sample Number: 1} \\
\hline 1 & Rotten eggs & 48 & 2.54 & 0.03 & 32 & Not detected & & \\
\hline 2 & Alcoholic & 293 & 3.2 & 0.19 & 32 & Ethanol & $64-17-5$ & \\
\hline 3 & Butterscotch 2 & 67 & 4.81 & 0.08 & 32 & Unknown & & \\
\hline 4 & Unknown neutral 1 & 59 & 5.31 & 0.08 & 32 & Isobutyl alcohol & $78-83-1$ & $\begin{array}{c}\text { 13: } 4333414239745556575375 \\
4954\end{array}$ \\
\hline 5 & Honey, caramel & 18 & 5.75 & 0.11 & 4 & Ethyl isobutyrate & $97-62-1$ & $\begin{array}{c}\text { 13: } 4371116418873894239101 \\
1177270\end{array}$ \\
\hline 6 & Floral, fruity & 17 & 6.91 & 0.08 & 4 & Ethyl butyrate & $105-54-4$ & $\begin{array}{c}\text { 17: } 71884373418960421017045 \\
3961116384737\end{array}$ \\
\hline 7 & Solvent & 18 & 7.2 & 0.07 & 4 & Unknown & & \\
\hline 8 & Over ripe fruit 1 & 23 & 7.56 & 0.09 & 4 & Unknown & & \\
\hline 9 & Over ripe fruit 2 & 18 & 8 & 0.16 & 4 & Not detected & & \\
\hline 10 & Fruity 2 & 121 & 8.27 & 0.08 & 32 & Ethyl isovalerate & $108-64-5$ & 6: 8885601158789 \\
\hline
\end{tabular}


Table A1. Cont.

\begin{tabular}{|c|c|c|c|c|c|c|c|c|}
\hline $\begin{array}{l}\text { Event } \\
\text { Number }\end{array}$ & Aroma Descriptor & $\begin{array}{l}\text { Weighted } \\
\text { Intensity }\end{array}$ & $\begin{array}{l}\text { Retention } \\
\text { time (min) }\end{array}$ & $\begin{array}{l}\text { Aroma Event } \\
\text { Width (min) }\end{array}$ & OD * & $\begin{array}{l}\text { Mass Spectral Library } \\
\text { Identification }\end{array}$ & $\begin{array}{l}\text { Chemical } \\
\text { Abstracts } \\
\text { Service } \\
\text { Number }\end{array}$ & $\begin{array}{c}\text { Significant Ions (Number of Ions } \\
\text { Listed: Ions Listed in the Order } \\
\text { of Intensity) }\end{array}$ \\
\hline 11 & Banana & 261 & 9.04 & 0.08 & 32 & Isoamyl acetate & $123-92-2$ & $\begin{array}{c}\text { 20: } 4370558761414273693971 \\
885856445785455354\end{array}$ \\
\hline 12 & Unknown pleasant & 32 & 11.32 & 0.09 & 32 & Unknown & & \\
\hline 13 & Fruity 3 & 38 & 12.22 & 0.1 & 4 & Not detected & & \\
\hline 14 & Garlic & 123 & 12.83 & 0.11 & 32 & Not detected & & \\
\hline 15 & Unknown neutral 2 & 9 & 15.18 & 0.09 & 4 & 2-Nonanone & $821-55-6$ & 9: 58435971578212784100 \\
\hline 16 & $\begin{array}{l}\text { Unknown } \\
\text { unpleasant }\end{array}$ & 132 & 15.7 & 0.1 & 32 & Unknown & & \\
\hline 17 & Rose & 76 & 15.91 & 0.16 & 32 & Unknown & & \\
\hline 18 & Matchstick & 71 & 16.7 & 0.08 & 32 & Unknown & & \\
\hline 19 & Cut grass & 327 & 17.06 & 0.2 & 32 & Ethyl octanoate & $106-32-1$ & $\begin{array}{c}\text { 20: } 88101127577073556041129 \\
\quad 6143115894269143833945\end{array}$ \\
\hline 20 & Barnyard & 39 & 18.43 & 0.16 & 32 & Unknown & & \\
\hline 21 & Mint & 28 & 19.3 & 0.07 & 32 & Unknown & & \\
\hline 22 & Unknown neutral 3 & 214 & 19.97 & 0.07 & 32 & Phenethyl alcohol & $60-12-8$ & 10: 91921226577789050104102 \\
\hline 23 & Strawberry 1 & 21 & 21.49 & 0.38 & 4 & Ethyl decanoate & $110-38-3$ & 20: 88101155157707355414361 \\
\hline 24 & Strawberry 2 & 393 & 22.01 & 0.16 & 32 & Octanoic acid & $124-07-2$ & $\begin{array}{c}\text { 20: } 434155115394542745653 \\
12711651797547128656350\end{array}$ \\
\hline 25 & Tomato 1 & 146 & 24.32 & 0.02 & 32 & Unknown & & \\
\hline 26 & Unknown neutral 4 & 194 & 24.78 & 0.02 & 32 & Unknown & & \\
\hline 27 & Unknown neutral 5 & 132 & 25.27 & 0.02 & 32 & Decanoic acid & $334-48-5$ & 20: 73601294155715743698783 \\
\hline \multicolumn{9}{|c|}{ Variety: Brianna; Harvest Time: 25 September 2015; Sample Number: 2} \\
\hline 1 & Rotten eggs & 63 & 2.54 & 0.03 & 32 & Not detected & & \\
\hline 2 & Alcoholic & 264 & 3.2 & 0.19 & 32 & Ethanol & $64-17-5$ & \\
\hline 3 & Butterscotch 1 & 3 & 4.2 & 0.38 & 1 & Not detected & & \\
\hline 4 & Butterscotch 2 & 16 & 4.81 & 0.08 & 8 & Not detected & & \\
\hline 5 & Body odor & 4 & 5.31 & 0.08 & 4 & Isobutyl alcohol & 78-83-1 & $\begin{array}{c}\text { 13: } 4333414239745556575375 \\
4954\end{array}$ \\
\hline 6 & Honey, caramel & 144 & 5.85 & 0.01 & 32 & Ethyl isobutyrate & $97-62-1$ & $\begin{array}{c}\text { 11: } 43718811689427310139 \\
7238\end{array}$ \\
\hline
\end{tabular}


Table A1. Cont.

\begin{tabular}{|c|c|c|c|c|c|c|c|c|}
\hline $\begin{array}{l}\text { Event } \\
\text { Number }\end{array}$ & Aroma Descriptor & $\begin{array}{l}\text { Weighted } \\
\text { Intensity }\end{array}$ & $\begin{array}{l}\text { Retention } \\
\text { time (min) }\end{array}$ & $\begin{array}{l}\text { Aroma Event } \\
\text { Width (min) }\end{array}$ & OD * & $\begin{array}{l}\text { Mass Spectral Library } \\
\text { Identification }\end{array}$ & $\begin{array}{c}\text { Chemical } \\
\text { Abstracts } \\
\text { Service } \\
\text { Number }\end{array}$ & $\begin{array}{c}\text { Significant Ions (Number of Ions } \\
\text { Listed: Ions Listed in the Order } \\
\text { of Intensity) }\end{array}$ \\
\hline 7 & Floral, fruity & 222 & 7.02 & -0.03 & 32 & Ethyl butyrate & $105-54-4$ & $\begin{array}{c}\text { 19: } 71884373608941704210161 \\
391167255102579074\end{array}$ \\
\hline 8 & Solvent & 114 & 7.3 & -0.03 & 32 & Unknown & & \\
\hline 9 & Over ripe fruit 2 & 122 & 8.04 & 0.06 & 32 & Not detected & & \\
\hline 10 & Over ripe fruit 2 & 80 & 8.23 & -0.07 & 32 & Isoamyl alcohol & $123-51-3$ & $\begin{array}{r}\text { 20: } 88101155157707355414361 \\
69608911557711438320042\end{array}$ \\
\hline 11 & Banana & 91 & 9.19 & -0.07 & 16 & Isoamyl acetate & $123-92-2$ & 4: 56435557 \\
\hline 12 & Unknown pleasant & 10 & 11.32 & 0.09 & 16 & Not detected & & \\
\hline 13 & Fruity 3 & 45 & 12.36 & -0.04 & 8 & Unknown & & \\
\hline 14 & Garlic & 61 & 12.83 & 0.11 & 32 & Not detected & & \\
\hline 15 & $\begin{array}{l}\text { Unknown } \\
\text { unpleasant }\end{array}$ & 37 & 15.7 & 0.1 & 8 & Unknown & & \\
\hline 16 & Rose & 1 & 15.91 & 0.16 & 1 & Unknown & & \\
\hline 17 & Matchstick & 33 & 16.7 & 0.08 & 32 & Unknown & & \\
\hline 18 & Cut grass & 96 & 17.14 & 0.12 & 16 & Not detected & & \\
\hline 19 & Barnyard & 3 & 18.43 & 0.16 & 8 & Unknown & & \\
\hline 20 & Mint & 39 & 19.3 & 0.07 & 32 & Propyl octanoate & $624-13-5$ & 9: 691211901051207712279145 \\
\hline 21 & Fruity 4 & 45 & 19.71 & 0.01 & 16 & Unknown & & \\
\hline 22 & Unknown neutral 3 & 140 & 20.02 & 0.02 & 32 & Phenethyl alcohol & $60-12-8$ & 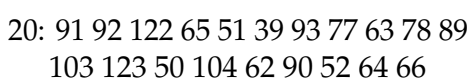 \\
\hline 23 & Strawberry 1 & 257 & 21.54 & 0.33 & 32 & Ethyl decanoate & $110-38-3$ & 9: 10610577515276753749 \\
\hline 24 & Strawberry 2 & 12 & 22.05 & 0.12 & 1 & Octanoic acid & $124-07-2$ & 16: 55697056848343411126867 \\
\hline 25 & Tomato 1 & 179 & 24.32 & 0.02 & 32 & Unknown & & \\
\hline 26 & Tomato 2 & 196 & 24.78 & 0.02 & 32 & Unknown & & \\
\hline 27 & Unknown neutral 5 & 180 & 25.27 & 0.02 & 32 & Decanoic acid & $334-48-5$ & $\begin{array}{c}\text { 20: } 73601295743554171698783 \\
\quad 61843914374424511256\end{array}$ \\
\hline \multicolumn{9}{|c|}{ Variety: Frontenac gris; Harvest Time: 24 September 2015; Sample Number: 1} \\
\hline 1 & Rotten eggs, sulfury & 7 & 2.54 & 2.04 & 2 & Not detected & & \\
\hline 2 & Alcoholic & 5 & 3.33 & 0.06 & 1 & Ethanol & $64-17-5$ & $\begin{array}{c}\text { 17: } 4546434247414433404877 \\
4961391043496\end{array}$ \\
\hline 3 & Butterscotch & 2 & 4.32 & 0.57 & 1 & Dimethylamine & $124-40-3$ & 2: 4440 \\
\hline 4 & Body odor & 0 & 5.31 & 0.08 & 1 & Isobutyl alcohol & $78-83-1$ & 4: 43414256 \\
\hline
\end{tabular}


Table A1. Cont.

\begin{tabular}{|c|c|c|c|c|c|c|c|c|}
\hline $\begin{array}{l}\text { Event } \\
\text { Number }\end{array}$ & Aroma Descriptor & $\begin{array}{l}\text { Weighted } \\
\text { Intensity }\end{array}$ & $\begin{array}{l}\text { Retention } \\
\text { time (min) }\end{array}$ & $\begin{array}{l}\text { Aroma Event } \\
\text { Width (min) }\end{array}$ & OD * & $\begin{array}{l}\text { Mass Spectral Library } \\
\text { Identification }\end{array}$ & $\begin{array}{l}\text { Chemical } \\
\text { Abstracts } \\
\text { Service } \\
\text { Number }\end{array}$ & $\begin{array}{l}\text { Significant Ions (Number of Ions } \\
\text { Listed: Ions Listed in the Order } \\
\text { of Intensity) }\end{array}$ \\
\hline 5 & $\begin{array}{l}\text { Honey, caramel, } \\
\text { butterscotch }\end{array}$ & 333 & 5.85 & 0.01 & 32 & Ethyl isobutyrate & $97-62-1$ & 11: 43714111688738942395553 \\
\hline 6 & Floral, fruity & 11 & 6.99 & 0 & 2 & Ethyl butyrate & $105-54-4$ & $\begin{array}{c}\text { 20: } 71884373416089421017045 \\
\quad 3961116725544907487\end{array}$ \\
\hline 7 & Solvent & 5 & 7.27 & 0 & 1 & Unknown & & \\
\hline 8 & Over ripe & 3 & 8.01 & 0.09 & 1 & Not detected & & \\
\hline 9 & Fruity 1 & 14 & 8.15 & 0.2 & 2 & Not detected & & \\
\hline 10 & Banana & 9 & 9.08 & 0.04 & 1 & Isoamyl acetete & $123-92-2$ & 20: $\begin{array}{c}4370558761414273693971 \\
8858565785455354115\end{array}$ \\
\hline 11 & $\begin{array}{l}\text { Unknown } \\
\text { pleasant } 1\end{array}$ & 0 & 11.32 & 0.09 & 1 & Unknown & & \\
\hline 12 & Fruity & 2 & 12.29 & 0.03 & 1 & Ethyl hexanoate & $123-66-0$ & $\begin{array}{c}\text { 20: } 88994310160707371416155 \\
421154539876911789100\end{array}$ \\
\hline 13 & Garlic & 1 & 12.83 & 0.11 & 1 & Not detected & & \\
\hline 14 & $\begin{array}{l}\text { Unknown } \\
\text { unpleasant } 2\end{array}$ & 19 & 15.7 & 0.1 & 2 & Methyl octanoate & $111-11-5$ & $\begin{array}{c}\text { 11: } 748712775115591019783 \\
12967\end{array}$ \\
\hline 15 & Cut grass, fruity & 9 & 17.15 & 0.11 & 1 & Ethyl octanoate & $106-32-1$ & $\begin{array}{c}\text { 20: } 8810112757737060554161 \\
43129115894269143458339\end{array}$ \\
\hline 16 & Floral & 5 & 19.5 & 0.54 & 1 & Unknown & & \\
\hline 17 & Strawberry, honey & 282 & 21.45 & 0.72 & 32 & Ethyl decanoate & $110-38-3$ & $\begin{array}{c}\text { 20: } 88101155157737055414360 \\
6169891155771143834284\end{array}$ \\
\hline 18 & Strawberry & 11 & 21.98 & 0.2 & 2 & Octanoic acid & $124-07-2$ & $\begin{array}{c}20: 607343101554184858761 \\
115453942575674835953\end{array}$ \\
\hline 19 & Tomato & 1 & 24.78 & 0.02 & 1 & Unknown & & \\
\hline 20 & Unknown neutral 2 & 0 & 25.27 & 0.02 & 1 & Decanoic acid & $334-48-5$ & $\begin{array}{r}\text { 20: } 6073129715787112172115 \\
45110391305982113687217344\end{array}$ \\
\hline \multicolumn{9}{|c|}{ Variety: Frontenac gris; Harvest Time: 24 September 2015; Sample Number: 2} \\
\hline 1 & Rotten eggs, sulfury & 67 & 2.59 & 0.08 & 32 & Not detected & & \\
\hline 2 & Alcoholic & 347 & 3.39 & 0.13 & 32 & Ethanol & $64-17-5$ & $\begin{array}{c}\text { 16: } 4546434247414433404877 \\
4939786179\end{array}$ \\
\hline 3 & $\begin{array}{l}\text { Honey, caramel, } \\
\text { butterscotch }\end{array}$ & 336 & 5.86 & 0.1 & 32 & Ethyl isobutyrate & $97-62-1$ & 10: 437188738939721015756 \\
\hline 4 & Honey & 64 & 6.53 & 0.04 & 32 & Isobutyl acetate & $110-19-0$ & 9: 435673615786745853 \\
\hline
\end{tabular}


Table A1. Cont.

\begin{tabular}{|c|c|c|c|c|c|c|c|c|}
\hline $\begin{array}{l}\text { Event } \\
\text { Number }\end{array}$ & Aroma Descriptor & $\begin{array}{l}\text { Weighted } \\
\text { Intensity }\end{array}$ & $\begin{array}{l}\text { Retention } \\
\text { time (min) }\end{array}$ & $\begin{array}{l}\text { Aroma Event } \\
\text { Width (min) }\end{array}$ & OD * & $\begin{array}{l}\text { Mass Spectral Library } \\
\text { Identification }\end{array}$ & $\begin{array}{c}\text { Chemical } \\
\text { Abstracts } \\
\text { Service } \\
\text { Number }\end{array}$ & $\begin{array}{l}\text { Significant Ions (Number of Ions } \\
\text { Listed: Ions Listed in the Order } \\
\text { of Intensity) }\end{array}$ \\
\hline 5 & Unknown pleasant & 259 & 7.09 & 0.07 & 32 & Ethyl butyrate & $105-54-4$ & $\begin{array}{c}\text { 20: } 71884341736089704210145 \\
3961116725544599069\end{array}$ \\
\hline 6 & Solvent & 213 & 7.38 & 0.07 & 32 & Unknown & & \\
\hline 7 & Body odor & 220 & 7.68 & 0.14 & 32 & Isoamyl alcohol & $123-51-3$ & $\begin{array}{c}\text { 15: } 5570424339457146445340 \\
54356052\end{array}$ \\
\hline 8 & Fruity 1 & 269 & 8.2 & 0.09 & 32 & Ethyl methylbutyrate & $7452-79-1$ & 6: 102857487115103 \\
\hline 9 & Fruity 2 & 85 & 8.4 & 0.09 & 32 & Ethyl isovalerate & $108-64-5$ & 10: 8885608761115865989130 \\
\hline 10 & Banana & 306 & 9.16 & 0.08 & 32 & Isoamyl acetete & $123-92-2$ & 20: $\begin{array}{c}4370558761414273693971 \\
884458565785455354\end{array}$ \\
\hline 11 & Woody 1 & 27 & 10.31 & 0.06 & 32 & Ethyl lactate & $97-64-3$ & 6: 457543476174 \\
\hline 12 & Vinegar & 37 & 11.45 & 0.06 & 32 & Acetic acid & $64-19-7$ & 6: 434560424144 \\
\hline 13 & Cereal & 100 & 11.75 & 0.39 & 32 & Unknown & & \\
\hline 14 & Fruity & 306 & 12.43 & 0.11 & 32 & Ethyl hexanoate & $123-66-0$ & $\begin{array}{c}\text { 20: } 88994310160707371614155 \\
\quad 421154539876911789102\end{array}$ \\
\hline 15 & Garlic & 102 & 12.89 & 0.11 & 32 & Not detected & & \\
\hline 16 & Mushroom & 52 & 14.95 & 0.06 & 32 & Unknown & & \\
\hline 17 & Sweaty & 250 & 15.74 & 0.45 & 32 & Methyl octanoate & $111-11-5$ & 6: 7487115599884 \\
\hline 18 & Match, sulfury & 88 & 16.74 & 0.08 & 32 & Not detected & & \\
\hline 19 & Cut grass, fruity & 340 & 17.26 & 0.19 & 32 & Ethyl octanoate & 106-32-1 & $\begin{array}{c}\text { 20: } 8810112757737060554161 \\
43129115894269143458339\end{array}$ \\
\hline 20 & Woody 2 & 63 & 18.23 & 0.12 & 32 & Unknown & & \\
\hline 21 & Rose 2 & 249 & 20.05 & 0.3 & 32 & Phenethyl alcohol & $60-12-8$ & $\begin{array}{c}\text { 20: } 91921226539517889103104 \\
1235062526466384176121\end{array}$ \\
\hline 22 & Strawberry, honey & 266 & 21.45 & 0.3 & 32 & Ethyl decanoate & $110-38-3$ & $\begin{array}{c}\text { 20: } 88101155157737055414360 \\
6169895711571143834284\end{array}$ \\
\hline 23 & Strawberry & 422 & 22.1 & 0.11 & 32 & Octanoic acid & $124-07-2$ & $\begin{array}{c}20: 6073434155101858487115 \\
\quad 61456939425756748382\end{array}$ \\
\hline 24 & Carrots, woody & 113 & 22.61 & 0.69 & 32 & Unknown & & \\
\hline 25 & Fecal & 55 & 23.4 & 0.02 & 32 & Unknown & & \\
\hline \multicolumn{9}{|c|}{ Variety: Frontenac gris; Harvest Time: 1 October 2015; Sample Number: 1} \\
\hline 1 & Rotten eggs, sulfury & 58 & 2.59 & 0.08 & 32 & Not detected & & \\
\hline 2 & Alcoholic & 361 & 3.39 & 0.13 & 32 & Ethanol & $64-17-5$ & $\begin{array}{c}\text { 16: } 4546434247414440337739 \\
496156115129\end{array}$ \\
\hline
\end{tabular}


Table A1. Cont.

\begin{tabular}{|c|c|c|c|c|c|c|c|c|}
\hline $\begin{array}{l}\text { Event } \\
\text { Number }\end{array}$ & Aroma Descriptor & $\begin{array}{l}\text { Weighted } \\
\text { Intensity }\end{array}$ & $\begin{array}{l}\text { Retention } \\
\text { time (min) }\end{array}$ & $\begin{array}{l}\text { Aroma Event } \\
\text { Width (min) }\end{array}$ & OD * & $\begin{array}{l}\text { Mass Spectral Library } \\
\text { Identification }\end{array}$ & $\begin{array}{l}\text { Chemical } \\
\text { Abstracts } \\
\text { Service } \\
\text { Number }\end{array}$ & $\begin{array}{l}\text { Significant Ions (Number of Ions } \\
\text { Listed: Ions Listed in the Order } \\
\text { of Intensity) }\end{array}$ \\
\hline 3 & $\begin{array}{l}\text { Honey, caramel, } \\
\text { butterscotch }\end{array}$ & 431 & 5.86 & 0.1 & 32 & Ethyl isobutyrate & $97-62-1$ & 11: 43714188116897244875570 \\
\hline 4 & Honey & 122 & 6.53 & 0.04 & 32 & Isobutyl acetate & $110-19-0$ & 9: 435673413971615737 \\
\hline 5 & Unknown pleasant & 307 & 7.09 & 0.07 & 32 & Ethyl butyrate & $105-54-4$ & $\begin{array}{c}\text { 19: } 7188437341607010142456 \text {. } \\
\quad 391165544578769117\end{array}$ \\
\hline 6 & Solvent & 291 & 7.38 & 0.07 & 32 & Unknown & & \\
\hline 7 & Body odor & 277 & 7.68 & 0.14 & 32 & Isoamyl alcohol & $123-51-3$ & $\begin{array}{c}\text { 16: } 5570424143394453405438 \\
5047377236\end{array}$ \\
\hline 8 & Fruity 1 & 314 & 8.2 & 0.09 & 32 & Ethyl methylbutyrate & $7452-79-1$ & 7: 10285871151037375 \\
\hline 9 & Fruity 2 & 112 & 8.4 & 0.09 & 32 & Ethyl isovalerate & $108-64-5$ & 7: 8885608711559103 \\
\hline 10 & Banana & 337 & 9.16 & 0.08 & 32 & Isoamyl acetete & $123-92-2$ & $\begin{array}{c}\text { 20: } 4370558761414273693971 \\
585688445785455354\end{array}$ \\
\hline 11 & Woody 1 & 55 & 10.31 & 0.06 & 32 & Ethyl lactate & $97-64-3$ & 5: 4575444756 \\
\hline 12 & Vinegar & 57 & 11.45 & 0.06 & 32 & Acetic acid & $64-19-7$ & 4: 43456042 \\
\hline 13 & Cereal & 138 & 11.75 & 0.39 & 32 & Unknown & & \\
\hline 14 & Fruity & 333 & 12.43 & 0.11 & 32 & Ethyl hexanoate & $123-66-0$ & $\begin{array}{l}\text { 20: } 88994310160707371416155 \\
\quad 42115453987691178974\end{array}$ \\
\hline $\begin{array}{l}15 \\
16\end{array}$ & $\begin{array}{l}\text { Garlic } \\
\text { Mushroom }\end{array}$ & $\begin{array}{c}129 \\
55\end{array}$ & $\begin{array}{l}12.89 \\
14.95\end{array}$ & 0.11 & $\begin{array}{l}32 \\
32\end{array}$ & Not detected & & \\
\hline $\begin{array}{l}16 \\
17\end{array}$ & Sweaty & 250 & 15.74 & 0.45 & 32 & Methyl octanoate & $111-11-5$ & 15: 7487127435755115594175 \\
\hline 18 & Rose 1 & 27 & 16.44 & 0.05 & 32 & Unknown & & \\
\hline 19 & Match, sulfury & 136 & 16.74 & 0.08 & 32 & Not detected & & \\
\hline 20 & Cut grass, fruity & 348 & 17.26 & 0.19 & 32 & Ethyl octanoate & $106-32-1$ & $\begin{array}{c}20: 8810112757737055604161 \\
12943115894269143834539\end{array}$ \\
\hline 21 & Woody 2 & 52 & 18.23 & 0.12 & 32 & Unknown & & \\
\hline 22 & Rose 2 & 290 & 20.05 & 0.3 & 32 & Phenethyl alcohol & $60-12-8$ & $\begin{array}{l}\text { 20: } 91921226551773993637889 \\
\quad 10350629052667964102\end{array}$ \\
\hline 23 & Strawberry, honey & 268 & 21.45 & 0.3 & 32 & Ethyl decanoate & $110-38-3$ & $\begin{array}{c}\text { 20: } 88101155157737055414360 \\
6169115895771143834284\end{array}$ \\
\hline 24 & Strawberry & 458 & 22.1 & 0.11 & 32 & Octanoic acid & $124-07-2$ & $\begin{array}{c}20: 607343551014185848769 \\
115614539425756748382\end{array}$ \\
\hline 25 & Carrots, woody & 156 & 22.61 & 0.69 & 32 & Unknown & & \\
\hline 26 & Fecal & 61 & 23.4 & 0.02 & 32 & Unknown & & \\
\hline
\end{tabular}


Table A1. Cont.

\begin{tabular}{|c|c|c|c|c|c|c|c|c|}
\hline $\begin{array}{l}\text { Event } \\
\text { Number }\end{array}$ & Aroma Descriptor & $\begin{array}{l}\text { Weighted } \\
\text { Intensity }\end{array}$ & $\begin{array}{l}\text { Retention } \\
\text { time (min) }\end{array}$ & $\begin{array}{l}\text { Aroma Event } \\
\text { Width (min) }\end{array}$ & OD * & $\begin{array}{l}\text { Mass Spectral Library } \\
\text { Identification }\end{array}$ & $\begin{array}{l}\text { Chemical } \\
\text { Abstracts } \\
\text { Service } \\
\text { Number }\end{array}$ & $\begin{array}{c}\text { Significant Ions (Number of Ions } \\
\text { Listed: Ions Listed in the Order } \\
\text { of Intensity) }\end{array}$ \\
\hline \multicolumn{9}{|c|}{ Variety: Frontenac gris; Harvest Time: 01 October 2015; Sample Number: 2} \\
\hline 1 & Rotten eggs, sulfury & 75 & 2.59 & 0.08 & 32 & Not detected & & \\
\hline 2 & Alcoholic & 391 & 3.39 & 0.13 & 32 & Ethanol & $64-17-5$ & $\begin{array}{c}\text { 14: } 4546434247414440337749 \\
393878\end{array}$ \\
\hline 3 & $\begin{array}{l}\text { Honey, caramel, } \\
\text { butterscotch }\end{array}$ & 423 & 5.86 & 0.1 & 32 & Ethyl isobutyrate & $97-62-1$ & $\begin{array}{c}\text { 13: } 4371418811673428910155 \\
729057\end{array}$ \\
\hline 4 & Honey & 87 & 6.53 & 0.04 & 32 & Isobutyl acetate & $110-19-0$ & $\begin{array}{c}\text { 12: } 43567341713961575586 \\
4438\end{array}$ \\
\hline 5 & Unknown pleasant & 324 & 7.09 & 0.07 & 32 & Ethyl butyrate & $105-54-4$ & $\begin{array}{c}\text { 20: } 71884341736089427010145 \\
\quad 396172554457408769\end{array}$ \\
\hline 6 & Solvent & 337 & 7.38 & 0.07 & 32 & Unknown & & \\
\hline 7 & Body odor & 359 & 7.68 & 0.14 & 32 & Isoamyl alcohol & $123-51-3$ & $\begin{array}{c}\text { 20: } 5570424143394571465340 \\
545150724935658648\end{array}$ \\
\hline 8 & Fruity 1 & 345 & 8.2 & 0.09 & 32 & Ethyl methylbutyrate & $7452-79-1$ & 6: 102858774103115 \\
\hline 9 & Fruity 2 & 122 & 8.4 & 0.09 & 32 & Ethyl isovalerate & $108-64-5$ & 7: 888560115877386 \\
\hline 10 & Banana & 382 & 9.16 & 0.08 & 32 & Isoamyl acetate & $123-92-2$ & 20: $\begin{array}{c}4370558761414273693971 \\
885658445785534554\end{array}$ \\
\hline 11 & Woody 1 & 49 & 10.31 & 0.06 & 32 & Ethyl lactate & $97-64-3$ & 6: 4575474610389 \\
\hline 12 & Vinegar & 38 & 11.45 & 0.06 & 32 & Acetic acid & 64-19-7 & 5: 4543604247 \\
\hline 13 & Cereal & 152 & 11.75 & 0.39 & 32 & Unknown & & \\
\hline 14 & Fruity & 419 & 12.43 & 0.11 & 32 & Ethyl hexanoate & $123-66-0$ & 20: 88994310160707371614155 \\
\hline 15 & Garlic & 207 & 12.89 & 0.11 & 32 & Not detected & & \\
\hline 16 & Mushroom & 48 & 14.95 & 0.06 & 32 & Unknown & & \\
\hline 17 & Sweaty & 372 & 15.74 & 0.45 & 32 & Methyl octanoate & $111-11-5$ & $\begin{array}{c}\text { 14: } 74871275557101115597584 \\
699885128\end{array}$ \\
\hline 18 & Rose 1 & 34 & 16.44 & 0.05 & 32 & Unknown & & \\
\hline 19 & Match, sulfury & 153 & 16.74 & 0.08 & 32 & Not detected & & \\
\hline 20 & Cut grass, fruity & 417 & 17.26 & 0.19 & 32 & Ethyl octanoate & $106-32-1$ & $\begin{array}{r}\text { 20: } 8810112757737055604161 \\
12943115894269143834539\end{array}$ \\
\hline 21 & Woody 2 & 71 & 18.23 & 0.12 & 32 & Unknown & & \\
\hline 22 & Rose 2 & 321 & 20.05 & 0.3 & 32 & Phenethyl alcohol & $60-12-8$ & $\begin{array}{c}\text { 20: } 919212265395177938978 \\
10310450123629052646638\end{array}$ \\
\hline
\end{tabular}


Table A1. Cont.

\begin{tabular}{|c|c|c|c|c|c|c|c|c|}
\hline $\begin{array}{l}\text { Event } \\
\text { Number }\end{array}$ & Aroma Descriptor & $\begin{array}{l}\text { Weighted } \\
\text { Intensity }\end{array}$ & $\begin{array}{l}\text { Retention } \\
\text { time (min) }\end{array}$ & $\begin{array}{l}\text { Aroma Event } \\
\text { Width (min) }\end{array}$ & OD * & $\begin{array}{l}\text { Mass Spectral Library } \\
\text { Identification }\end{array}$ & $\begin{array}{l}\text { Chemical } \\
\text { Abstracts } \\
\text { Service } \\
\text { Number }\end{array}$ & $\begin{array}{c}\text { Significant Ions (Number of Ions } \\
\text { Listed: Ions Listed in the Order } \\
\text { of Intensity) }\end{array}$ \\
\hline 23 & Strawberry, honey & 321 & 21.45 & 0.3 & 32 & Ethyl decanoate & $110-38-3$ & $\begin{array}{c}\text { 20: } 88101155157737055414360 \\
\quad 6169891155771143834284\end{array}$ \\
\hline 24 & Strawberry & 517 & 22.1 & 0.11 & 32 & Octanoic acid & $124-07-2$ & $\begin{array}{c}20: 607343101554185848769 \\
115614539425756748359\end{array}$ \\
\hline 25 & Carrots, woody & 178 & 22.61 & 0.69 & 32 & Unknown & & \\
\hline 26 & Fecal & 58 & 23.4 & 0.02 & 32 & Unknown & & \\
\hline \multicolumn{9}{|c|}{ Variety: Frontenac gris; Harvest Time: 09 October 2015; Sample Number: 1} \\
\hline 1 & Rotten eggs, sulfury & 78 & 2.59 & 0.08 & 32 & Not detected & & \\
\hline 2 & Alcoholic & 355 & 3.39 & 0.13 & 32 & Ethanol & $64-17-5$ & $\begin{array}{c}\text { 17: } 4546434247414440337749 \\
396178553453\end{array}$ \\
\hline 3 & Unknown neutral 1 & 5 & 4.16 & 0.03 & 2 & Not detected & & \\
\hline 4 & $\begin{array}{l}\text { Honey, caramel, } \\
\text { butterscotch }\end{array}$ & 378 & 5.86 & 0.1 & 32 & Ethyl isobutyrate & $97-62-1$ & $\begin{array}{c}\text { 13: } 4371411168873891013942 \\
7270117\end{array}$ \\
\hline 5 & Honey & 60 & 6.53 & 0.04 & 32 & Isobutyl acetate & $110-19-0$ & 7: 43567339576186 \\
\hline 6 & Unknown pleasant & 296 & 7.09 & 0.07 & 32 & Ethyl butyrate & $105-54-4$ & $\begin{array}{c}\text { 20: } 71884373416089704210145 \\
\quad 3961721165544405738\end{array}$ \\
\hline 7 & Solvent & 296 & 7.38 & 0.07 & 32 & Unknown & & \\
\hline 8 & Body odor & 318 & 7.68 & 0.14 & 32 & Isoamyl alcohol & $123-51-3$ & $\begin{array}{c}\text { 20: } 5570424143394569714644 \\
403851503773498685\end{array}$ \\
\hline 9 & Fruity 1 & 289 & 8.2 & 0.09 & 32 & Ethyl methylbutyrate & $7452-79-1$ & 6: 102857411587103 \\
\hline 10 & Fruity 2 & 170 & 8.4 & 0.09 & 32 & Ethyl isovalerate & $108-64-5$ & 8: 88856061875973103 \\
\hline 11 & Banana & 374 & 9.16 & 0.08 & 32 & Isoamyl acetate & $123-92-2$ & 20: $\begin{array}{c}4370558761414273693971 \\
568844585785455354\end{array}$ \\
\hline 12 & Woody 1 & 47 & 10.31 & 0.06 & 32 & Ethyl lactate & $97-64-3$ & 2: 4575 \\
\hline 13 & Vinegar & 35 & 11.45 & 0.06 & 32 & Acetic acid & $64-19-7$ & 7: 45436042444772 \\
\hline 14 & Cereal & 145 & 11.75 & 0.39 & 32 & Unknown & & \\
\hline 15 & Fruity & 416 & 12.43 & 0.11 & 32 & Ethyl hexanoate & $123-66-0$ & $\begin{array}{c}\text { 20: } 88994310160707371614155 \\
421154539876911789102\end{array}$ \\
\hline 16 & Garlic & 168 & 12.89 & 0.11 & 32 & Not detected & & \\
\hline 17 & Mushroom & 61 & 14.95 & 0.06 & 32 & Unknown & & \\
\hline 18 & Sweaty & 384 & 15.74 & 0.45 & 32 & Methyl octanoate & $111-11-5$ & 9: 7487115575975849883 \\
\hline 19 & Rose 1 & 39 & 16.44 & 0.05 & 32 & Unknown & & \\
\hline 20 & Match, sulfury & 134 & 16.74 & 0.08 & 32 & Not detected & & \\
\hline
\end{tabular}


Table A1. Cont.

\begin{tabular}{|c|c|c|c|c|c|c|c|c|}
\hline $\begin{array}{l}\text { Event } \\
\text { Number }\end{array}$ & Aroma Descriptor & $\begin{array}{l}\text { Weighted } \\
\text { Intensity }\end{array}$ & $\begin{array}{l}\text { Retention } \\
\text { time (min) }\end{array}$ & $\begin{array}{l}\text { Aroma Event } \\
\text { Width (min) }\end{array}$ & OD * & $\begin{array}{l}\text { Mass Spectral Library } \\
\text { Identification }\end{array}$ & $\begin{array}{c}\text { Chemical } \\
\text { Abstracts } \\
\text { Service } \\
\text { Number }\end{array}$ & $\begin{array}{c}\text { Significant Ions (Number of Ions } \\
\text { Listed: Ions Listed in the Order } \\
\text { of Intensity) }\end{array}$ \\
\hline 21 & Cut grass, fruity & 381 & 17.26 & 0.19 & 32 & Ethyl octanoate & $106-32-1$ & $\begin{array}{c}\text { 20: } 8810112757737055604161 \\
12943115428969143834539\end{array}$ \\
\hline 22 & Woody 2 & 78 & 18.23 & 0.12 & 32 & Unknown & & \\
\hline 23 & Rose 2 & 319 & 20.05 & 0.3 & 32 & Phenethyl alcohol & $60-12-8$ & 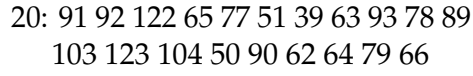 \\
\hline 24 & Strawberry, honey & 336 & 21.45 & 0.3 & 32 & Ethyl decanoate & $110-38-3$ & $\begin{array}{c}\text { 20: } 88101155157737055414360 \\
6169115895771143834285\end{array}$ \\
\hline 25 & Strawberry & 457 & 22.1 & 0.11 & 32 & Octanoic acid & $124-07-2$ & $\begin{array}{c}20: 6073431015541858487115 \\
69613945425756748397\end{array}$ \\
\hline 26 & Carrots, woody & 155 & 22.61 & 0.69 & 32 & Unknown & & \\
\hline 27 & Fecal & 97 & 23.4 & 0.02 & 32 & Unknown & & \\
\hline \multicolumn{9}{|c|}{ Variety: Frontenac gris; Harvest Time: 9 October 2015; Sample Number: 2} \\
\hline 1 & Rotten eggs, sulfury & 61 & 2.59 & 0.08 & 32 & Not detected & & \\
\hline 2 & Alcoholic & 304 & 3.39 & 0.13 & 32 & Ethanol & $64-17-5$ & $\begin{array}{c}\text { 15: } 4546434247414433404877 \\
49396134\end{array}$ \\
\hline 3 & Unknown neutral 1 & 0 & 4.15 & 0.02 & 1 & Not detected & & \\
\hline 4 & $\begin{array}{l}\text { Honey, caramel, } \\
\text { butterscotch }\end{array}$ & 320 & 5.86 & 0.1 & 32 & Ethyl isobutyrate & $97-62-1$ & 8: 43714188116738972 \\
\hline 5 & Honey & 41 & 6.53 & 0.04 & 32 & Isobutyl acetate & $110-19-0$ & $\begin{array}{c}\text { 14: } 4356734139715786745544 \\
6058101\end{array}$ \\
\hline 6 & Unknown pleasant & 268 & 7.09 & 0.07 & 32 & Ethyl butyrate & $105-54-4$ & 19: 7188437341608942704539 \\
\hline 7 & Solvent & 292 & 7.38 & 0.07 & 32 & Unknown & & \\
\hline 8 & Body odor & 349 & 7.68 & 0.14 & 32 & Isoamyl alcohol & $123-51-3$ & $\begin{array}{c}\text { 16: } 5570424339697146535450 \\
5960725265\end{array}$ \\
\hline 9 & Fruity 1 & 23 & 8.2 & 0.09 & 2 & Ethyl methylbutyrate & $7452-79-1$ & 6: 102857411587103 \\
\hline 10 & Fruity 2 & 244 & 8.4 & 0.09 & 32 & Ethyl isovalerate & $108-64-5$ & 8: 88856061871155973 \\
\hline 11 & Banana & 373 & 9.16 & 0.08 & 32 & Isoamyl acetate & $123-92-2$ & 20: $\begin{array}{c}4370558761414273693971 \\
885644585785455354\end{array}$ \\
\hline 12 & Woody 1 & 32 & 10.31 & 0.06 & 32 & Ethyl lactate & $97-64-3$ & 3: 457576 \\
\hline 13 & Vinegar & 30 & 11.45 & 0.06 & 32 & Acetic acid & 64-19-7 & 7: 43456042416147 \\
\hline 14 & Cereal & 147 & 11.75 & 0.39 & 32 & Unknown & & \\
\hline
\end{tabular}


Table A1. Cont.

\begin{tabular}{|c|c|c|c|c|c|c|c|c|}
\hline $\begin{array}{l}\text { Event } \\
\text { Number }\end{array}$ & Aroma Descriptor & $\begin{array}{l}\text { Weighted } \\
\text { Intensity }\end{array}$ & $\begin{array}{l}\text { Retention } \\
\text { time (min) }\end{array}$ & $\begin{array}{l}\text { Aroma Event } \\
\text { Width (min) }\end{array}$ & OD * & $\begin{array}{l}\text { Mass Spectral Library } \\
\text { Identification }\end{array}$ & $\begin{array}{c}\text { Chemical } \\
\text { Abstracts } \\
\text { Service } \\
\text { Number }\end{array}$ & $\begin{array}{c}\text { Significant Ions (Number of Ions } \\
\text { Listed: Ions Listed in the Order } \\
\text { of Intensity) }\end{array}$ \\
\hline 15 & Fruity & 389 & 12.43 & 0.11 & 32 & Ethyl hexanoate & $123-66-0$ & $\begin{array}{c}\text { 20: } 88994310160707371614155 \\
421154539876911789100\end{array}$ \\
\hline 16 & Garlic & 145 & 12.89 & 0.11 & 32 & Not detected & & \\
\hline 17 & Mushroom & 63 & 14.95 & 0.06 & 32 & Unknown & & \\
\hline 18 & Sweaty & 358 & 15.74 & 0.45 & 32 & Methyl octanoate & $111-11-5$ & $\begin{array}{c}\text { 11: } 748712775115591019783 \\
12967\end{array}$ \\
\hline 19 & Rose 1 & 132 & 16.44 & 0.05 & 32 & Unknown & & \\
\hline 20 & Match, sulfury & 183 & 16.74 & 0.08 & 32 & Not detected & & \\
\hline 21 & Cut grass, fruity & 394 & 17.26 & 0.19 & 32 & Ethyl octanoate & $106-32-1$ & $\begin{array}{c}\text { 20: } 8810112757737055604161 \\
12943115894269143834539\end{array}$ \\
\hline 22 & Woody 2 & 102 & 18.23 & 0.12 & 32 & Unknown & & \\
\hline 23 & Rose 2 & 321 & 20.05 & 0.3 & 32 & Phenethyl alcohol & $60-12-8$ & 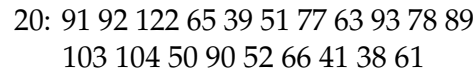 \\
\hline 24 & Strawberry, honey & 395 & 21.45 & 0.3 & 32 & Ethyl decanoate & $110-38-3$ & 20: 88101155157737055414360 \\
\hline 25 & Strawberry & 524 & 22.1 & 0.11 & 32 & Octanoic acid & $124-07-2$ & 20: $\begin{array}{c}60734355101418584876961 \\
1153945425756748359\end{array}$ \\
\hline 26 & Carrots, woody & 155 & 22.61 & 0.69 & 32 & Unknown & & \\
\hline 27 & Fecal & 117 & 23.4 & 0.02 & 32 & Unknown & & \\
\hline
\end{tabular}




\section{References}

1. Wine America Economic Impact Reports. Available online: http://wineamerica.org/impact (accessed on 20 August 2018).

2. White, M.L. History of the Institute. In Proceedings of the Midwest Grape and Wine Industry Institute Advisory Board Meeting Minutes, Interpower Building, Ames, IA, USA, 6 July 2017.

3. Tuck, B.; Gartner, W.; Appiah, G. Economic Contribution of Vineyards and Wineries of the North. 2015. Available online: https://conservancy.umn.edu/bitstream/handle/11299/197808/2015-economic-contributionwineries-and-grapes.pdf?sequence=1\&isAllowed=y (accessed on 20 August 2018).

4. Parker, M.; Capone, D.L.; Francis, I.L.; Herderich, M.J. Aroma precursors in grapes and wine: Flavor release during wine production and consumption. J. Agric. Food Chem. 2018, 10, 2281-2286. [CrossRef]

5. Gonzalez, R.; Morales, P. Wine secondary aroma: Understanding yeast production of higher alcohols. Microb. Biotechnol. 2017, 10, 1149-1450. [CrossRef] [PubMed]

6. Rapp, A. Volatile flavour of wine: Correlation between instrumental analysis and sensory perception. Nahrung 1998, 42, 351-363. [CrossRef]

7. Acree, T.; Arn, H. Flavornet and Human Odor Space. Available online: http://www.flavornet.org (accessed on 20 August 2018).

8. LRI \& Odour Database. Available online: http://www.odour.org.uk/index.html (accessed on 20 August 2018).

9. Boulton, R.B.; Singleton, V.L.; Bisson, L.F.; Kunkee, R.E. Principles and Practices of Winemaking; CBS Publishers \& Distributors Pvt. Ltd.: New Delhi, India, 1996; pp. 18-20. ISBN 81-239-0522-X.

10. Jordão, A.M.; Vilela, A.; Cosme, F. From sugar of grape to alcohol of wine: Sensorial impact of alcohol in wine. Beverages 2015, 1, 292-310. [CrossRef]

11. Okie, W.R. Register of new fruit and nut varieties, List 42. HortScience 2004, 39, 1509-1523.

12. Luby, J.; Hemstad, P. Grape Plant Named 'Frontenac Gris'. Regents of the University of Minnesota, Minneapolis, MN (US), assignee. U.S. Patent PP16,478 P3, 25 April 2006. Print.

13. Frontenac Gris Wine. University of Minnesota Cold Hardy Grapes. Available online: http://www.grapes. umn.edu/gris/enology.html (accessed on 20 August 2018).

14. Atucha, A.; Hedtcke, J.; Workmaster, B.A. Evaluation of cold-climate interspecific hybrid wine grape cultivars for the upper Midwest. J. Am. Pomol. Soc. 2018, 72, 80-93.

15. Cai, L.; Rice, S.; Koziel, J.A.; Dharmadhikari, M. Development of an automated method for aroma analysis of red wines from cold-hardy grapes using simultaneous solid-phase microextraction-Multidimensional gas chromatography-Mass spectrometry-Olfactometry. Separations 2017, 4, 24. [CrossRef]

16. Pawliszyn, J. Handbook of Solid Phase Microextraction; Chemical Industry Press of China: Beijing, China, 2009.

17. Wang, X.; Tao, Y.; Wu, Y.; An, R.; Yue, Z. Aroma compounds and characteristics of noble-rot wines of Chardonnay grapes artificially botrytized in the vineyard. Food Chem. 2017, 226, 41-50. [CrossRef]

18. Bordiga, M.; Rinaldi, M.; Locatelli, M.; Piana, G.; Travaglia, F.; Coïsson, J.D.; Arlorio, M. Characterization of Muscat wines aroma evolution using comprehensive gas chromatography followed by a post-analytic approach to 2D contour plots comparison. Food Chem. 2013, 140, 57-67. [CrossRef]

19. Wenlai, F.; Yan, X.; Wenguang Jiang, A.J.L.; Jiming, L. Identification and quantification of impact aroma compounds in 4 nonfloral Vitis vinifera varieties grapes. J. Food Sci. 2010, 75. [CrossRef]

20. Sun, Q.; Gates, M.J.; Lavin, E.H.; Acree, T.E.; Sacks, G.L. Comparison of odor-active compounds in grapes and wines from vitis vinifera and non-foxy American grape species. J. Agric. Food Chem. 2011, 59, 10657-10664. [CrossRef] [PubMed]

21. The Northern Grapes Project: Viticulture, Enology and Marketing for Cold-Hardy Grapes. Available online: http://northerngrapesproject.org (accessed on 31 December 2018).

22. Rice, S.; Lutt, N.; Koziel, J.A.; Dharmadhikari, M.; Fennell, A. Determination of selected aromas in Marquette and Frontenac wine using headspace-SPME coupled with GC-MS and simultaneous olfactometry. Separations 2018, 5, 20. [CrossRef]

23. Cai, L.; Rice, S.; Koziel, J.A.; Jenks, W.S.; van Leeuwen, J.H. Further purification of food-grade alcohol to make a congener-free product. J. Inst. Brew. 2016, 122, 84-92. [CrossRef]

24. The Good Scents Company Information System. Available online: http://www.thegoodscentscompany.com/ (accessed on 20 August 2018). 
25. Onuki, S.; Koziel, J.A.; Jenks, W.S.; Cai, L.; Rice, S.; van Leeuwen, J.H. Optimization of extraction parameters for quantification of fermentation volatile by-products in industrial ethanol with solid-phase microextraction and gas chromatography. J. Inst. Brew. 2016, 122, 102-109. [CrossRef]

26. Rice, S.; Koziel, J.A. Characterizing the smell of marijuana by odor impact of volatile compounds: An application of simultaneous chemical and sensory analysis. PLoS ONE 2015, 10. [CrossRef] [PubMed]

27. Rice, S.; Koziel, J.A. Odor impact of volatiles emitted from marijuana, cocaine, heroin and their surrogate scents. Data Brief 2015, 5, 653-706. [CrossRef]

28. Rice, S.; Koziel, J.A. The relationship between chemical concentration and odor activity value explains the inconsistency in making a comprehensive surrogate scent training tool representative of illicit drugs. Forensic Sci. Int. 2015, 257, 257-270. [CrossRef]

29. Reboredo-Rodríguez, P.; González-Barreiro, C.; Rial-Otero, R.; Cancho-Grande, B.; Simal-Gándara, J. Effects of sugar concentration processes in grapes and wine aging on aroma compounds of sweet wines-A review. Crit. Rev. Food Sci. Nutr. 2015, 55, 1053-1073. [CrossRef]

30. Camper, C. Chateau Stripmine-Brianna Parentage. Available online: http://chateaustripmine.info/Parentage/ Brianna.gif (accessed on 5 September 2018).

31. Camper, C. Chateau Stripmine-Frontenac Parentage. Available online: http://chateaustripmine.info/ Parentage/Frontenac.gif (accessed on 5 September 2018).

32. Jackson, R.S. Wine Science Principles and Applications; Elsevier: Amsterdam, The Netherlands, 2008; ISBN 978-0-12-373646-8.

33. González-Álvarez, M.; Noguerol-Pato, R.; González-Barreiro, C.; Cancho-Grande, B.; Simal-Gándara, J. Sensory quality control of young vs. aged sweet wines obtained by the techniques of both postharvest natural grape dehydration and fortification with spirits during vinification. Food Anal. Method 2013, 6, 289-300. [CrossRef]

34. Noguerol-Pato, R.; González-Álvarez, M.; González-Barreiro, C.; Cancho-Grande, B.; Simal-Gándara, J. Evolution of the aromatic profile in Garnacha Tintorera grapes during raisining and comparison with that of the naturally sweet wine obtained. Food Chem. 2013, 139, 1052-1061. [CrossRef]

35. Mauricio, J.C.; Moreno, J.; Zea, L.; Ortega, J.M.; Medina, M. The effects of grape must fermentation conditions on volatile alcohols and esters formed by Saccharomyces cerevisiae. J. Sci. Food Agric. 1997, 75, 155-160. [CrossRef]

36. Simpson, R.F.; Miller, G.C. Aroma composition of Chardonnay wine. Vitis 1984, 23, 143-158.

37. Straus, C.R.; Wilson, B.; Anderson, R.; Williams, P.J. Application of droplet countercurrent chromatography to the analysis of conjugated forms of terpenoids, phenols, and other constituents of grape juice. J. Agric. Food Chem. 1987, 35, 519-524. [CrossRef]

38. Ferreira, V.; Pena, C.; Escudero, C.L.; Fernandez, P.; Cacho, J. Method for the HPLC prefractionation of wine flavour extracts. Part II-Sensory aspects. Profiling wine aroma. In Progress in Food Fermentation; Benedito, C., Collar, C., Martinez, M., Morel, J., Eds.; IATA: Valencia, Spain, 1993; Volume 2, pp. 69-74.

39. Marais, J.; Pool, H.J. Effect of storage time and temperature on the volatile composition and quality of dry white table wines. Vitis 1980, 19, 151-164.

40. Marais, J. Terpenes in the Aroma of Grapes and Wines; A review. S. Afr. J. Enol. Vitic. 1983, 4, 49-58. [CrossRef]

41. Cullere, L.; Escudero, E.C.; Campo, E.; Cacho, J.; Ferreira, V. Multidimensional gas chromatography-mass spectrometry determination of 3-alkyl-2-methoxypyrazines in wine and must. A comparison of solid-phase extraction and headspace solid-phase extraction methods. J. Chromatogr. A 2009, 1216, 4040-4045. [CrossRef]

42. Kolor, M.K. Identification of an important new flavor compound in Concord grape, ethyl 3-mercaptopropionate. J. Agric. Food Chem. 1983, 31, 1125-1127. [CrossRef]

43. Tominaga, T.; Niclass, Y.; Frerot, E.; Dubourdiue, D. Stereoisomeric distribution of 3-mercaptohexan-1-ol and 3-mercaptohexyl acetate in dry and sweet white wines made from Vitis vinifera (Var. Sauvignon Blanc and Semillon). J. Agric. Food Chem. 2006, 54, 7251-7255. [CrossRef] [PubMed]

44. Guth, H. Identification of character impact odorants of different white wine varieties. J. Agric. Food Chem. 1997, 45, 3022-3026. [CrossRef]

45. Winton, W.; Ough, C.S.; Singleton, V.L. Relative distinctiveness of varietal wines estimated by the ability of trained panelists to name the grape variety correctly. Am. J. Enol. Vitic. 1975, 26, 5-11. 
46. González-Barreiro, C.; Rial-Otero, R.; Cancho-Grande, B.; Simal-Gándara, J. Wine aroma compounds in grapes: A critical review. Crit. Rev. Food Sci. Nutr. 2015, 55, 202-218. [CrossRef] [PubMed]

47. Mansfield, A.K.; Vickers, Z.M. Characterization of the aroma of red Frontenac table wines by descriptive analysis. Am. J. Enol. Vitic. 2009, 60, 435-441.

48. Mansfield, A.K.; Schirle-Keller, J.P.; Reineccius, G.A. Identification of odor-impact compounds in red table wines produced from Frontenac grapes. Am. J. Enol. Vitic. 2011, 62, 169-176. [CrossRef]

49. Pedneault, K.; Dorais, M.; Angers, P. Flavor of cold-hardy grapes: Impact of berry maturity and environmental conditions. J. Agric. Food Chem. 2013, 64, 10418-10438. [CrossRef] [PubMed]

50. Slegers, A.; Angers, P.; Ouillet, E.; Truchon, T.; Pedneault, K. Volatile compounds from grape skin, juice and wine from five interspecific hybrid grape cultivars grown in Quebec (Canada) for wine production. Molecules 2015, 20, 10980-11016. [CrossRef] [PubMed]

51. Brady, J.M. Descriptive Analysis of Frontenac gris and Brianna Wine Grape and Wine Varieties. Retrieved from the University of Minnesota Digital Conservancy. Available online: http://hdl.handle.net/11299/194662 (accessed on 20 December 2018).

52. Sanchez-Palomo, E.; Diaz-Maroto, M.C.; Gonzalez-Vinas, M.A.; Soriano-Perez, A.; Perez-Coello, M.S. Aroma profile of wines from Albillo and Muscat grape varieties at different stages of ripening. Food Control 2005, 18, 398-403. [CrossRef]

53. Bindon, K.; Varela, C.; Kennedy, J.; Holt, H.; Herderich, M. Relationships between harvest time and wine composition in Vitis vinifera L. cv. Cabernet Sauvignon 1. Grape and wine chemistry. Food Chem. 2013, 138, 1696-1705. [CrossRef] [PubMed]

54. Gomez-Miguez, M.J.; Gomez-Miguez, M.; Vicario, I.M.; Heredia, F.J. Assessment of colour and aroma in white wines vinifications: Effects of grape maturity and soil type. J. Food Eng. 2007, 79, 758-764. [CrossRef]

55. Vilanova, M.; Genisheva, Z.; Bescansa, L.; Masa, A.; Oliveira, J. Changes in free and bound fractions of aroma compounds of four Vitis vinifera cultivars at the last ripening stages. Phytochemistry 2012, 74, 196-205. [CrossRef]

56. Yuan, F.; Qian, M. Quantification of selected aroma-active compounds in Pinot noir wines from different grape maturities. J. Agric. Food Chem. 2006, 54, 8567-8573. [CrossRef]

57. Yuan, F.; Qian, M.C. Aroma potential in early- and late-maturity Pinot noir grapes evaluated by aroma extract dilution analysis. J. Agric. Food Chem. 2016, 64, 443-450. [CrossRef] [PubMed]

58. Jiang, B.; Zhang, Z.-W. A Preliminary study of aroma composition and impact odorants of Cabernet Franc wines under different terrain conditions of the Loess Plateau Region (China). Molecules 2018, 23, 1096. [CrossRef]

59. Zhao, P.; Gao, J.; Qian, M.; Li, H. Characterization of the key aroma compounds in Chinese Syrah wine by gas chromatography-olfactometry-mass spectrometry and aroma reconstitution studies. Molecules 2017, 22, 1045. [CrossRef] [PubMed]

60. Liu, P.-H.; Vrigneau, C.; Salmon, T.; Hoang, D.A.; Boulet, J.-C.; Jégou, S.; Marchal, R. Influence of grape berry maturity on juice and base wine composition and foaming properties of sparkling wines from the Champagne region. Molecules 2018, 23, 1372. [CrossRef] [PubMed]

61. Ristic, R.; Boss, P.K.; Wilkinson, K.L. Influence of fruit maturity at harvest on the intensity of smoke taint in wine. Molecules 2015, 20, 8913-8927. [CrossRef] [PubMed]

62. Zhang, P.; Luo, F.; Howell, K. Fortification and elevated alcohol concentration affect the concentration of rotundone and volatiles in Vitis vinifera cv. Shiraz Wine. Fermentation 2017, 3, 29. [CrossRef]

63. Gonzalez-Alvarez, M.; Gonzalez-Barreiro, C.; Cancho-Grande, B.; Simall-Gandara, J. Relationship between Godello white wine sensory properties and its aromatic fingerprinting obtained by GC-MS. Food Chem. 2011, 129, 890-898. [CrossRef]

64. Noguerol-Pato, R.; Gonzalez-Alvarez, M.; Gonzalez-Barreiro, C.; Cancho-Grande, B.; Simal-Gandara, J. Aroma profile of Garnacha Tintorera-based sweet wines by chromatographic and sensorial analysis. Food Chem. 2012, 134, 2313-2325. [CrossRef]

65. Noguerol-Pato, R.; Gonzalez-Barreiro, C.; Cancho-Grande, B.; Santiago, J.L.; Martinez, M.C.; Simal-Gandara, J. Aroma potential of Brancellao grapes from different cluster positions. Food Chem. 2011, 132, 112-124. [CrossRef] 
66. Noguerol-Pato, R.; González-Barreiro, C.; Simal-Gándara, J.; Martínez, M.C.; Santiago, J.L.; Cancho-Grande, B. Active odorants in Mouratón grapes from shoulders and tips into the bunch. Food Chem. 2012, 133, 1362-1372. [CrossRef]

67. Noguerol-Pato, R.; González-Barreiro, C.; Cancho-Grande, B.; Martínez, M.C.; Santiago, J.L.; Simal-Gándara, J. Floral, spicy and herbaceous active odorants in Gran Negro berries from shoulders and tips into the cluster, and comparison with Brancellao and Mouratón varieties. Food Chem. 2012, 135, 2771-2782. [CrossRef] [PubMed]

68. Rice, S.; Koziel, J.A.; Dharmadhikari, M.; Fennell, A. Evaluation of tannins and anthocyanins in Marquette, Frontenac, and St. Croix cold-hardy grape cultivars. Fermentation 2017, 3, 47. [CrossRef]

(C) 2019 by the authors. Licensee MDPI, Basel, Switzerland. This article is an open access article distributed under the terms and conditions of the Creative Commons Attribution (CC BY) license (http://creativecommons.org/licenses/by/4.0/). 